\title{
RUBY AND SAPPHIRE FROM JEGDALEK, AFGHANISTAN
}

\author{
By Gary W. Bowersox, Eugene E. Foord, Brendan M. Laurs, \\ James E. Shigley, and Christopher P. Smith
}

This study provides detailed mining and gemological information on the Jegdalek deposit, in east-central Afghanistan, which is hosted by elongate beds of corundum-bearing marble. Some facet-grade ruby has been recovered, but most of the material consists of semitransparent pink sapphire of cabochon or carving quality. The most common internal features are dense concentrations of healed and nonhealed fracture planes and lamellar twin planes. Color zoning is common, and calcite, apatite, zircon, mica, iron sulfide minerals, graphite, rutile, aluminum hydroxide, and other minerals are also present in some samples. Although the reserves appear to be large, future potential will depend on the establishment of a stable government and the introduction of modern mining and exploration techniques.

\section{ABOUT THE AUTHORS}

Mr. Bowersox (MrGary77@aol.com) is president of GeoVision, Inc., Honolulu, Hawaii, and has been active in Afghanistan since 1972. Dr.

Foord (deceased) was a research geologistmineralogist with the U.S. Geological Survey,

Denver, Colorado. Mr. Laurs is senior editor of Gems \& Gemology, and Dr. Shigley is director of GIA Research, at GIA in Carlsbad, California. Mr. Smith (cps@gemkey.com) is director of the Gübelin Gem Lab, Lucerne, Switzerland.

Please see acknowledgments at the end of the article.

Gems \& Gemology, Vol. 36, No. 2, pp. 110-126 (C) 2000 Gemological Institute of America

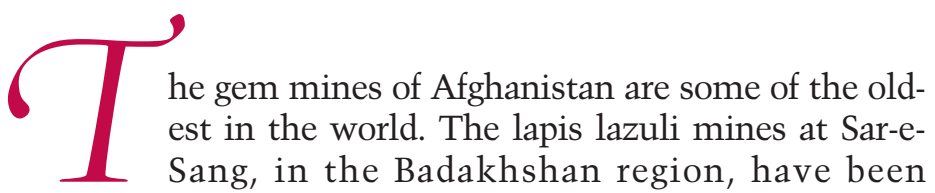
worked for at least 6,500 years (see, e.g., Wyart et al., 1981). Today, Afghanistan continues to be an important source of various gem minerals-including emerald, ruby, sapphire, aquamarine, tourmaline, and spodumene (see, e.g., Bowersox and Chamberlin, 1995). Yet relatively little is known about many of the gem localities.

This article reports on the only known source of ruby in Afghanistan: the Jegdalek region. A historical review, the geology, mining methods, and current production of gem corundum (figure 1) from Jegdalek are given below, together with the results of our research on the gemological properties of this material.

\section{BACKGROUND}

Although most of the records of the Ministry of Mines and Industry have been destroyed by the rocket attacks and bombs that have plagued Kabul since 1979, we were able to glean a fair amount of information from the literature. The geographic location of Afghanistan among several powerful neighbors (i.e., China, Iran, Pakistan, Uzbekistan, Tajikistan, and Turkmenistan; figure 2) has resulted in a long history of turmoil. Additionally, invasions by the Greeks (327 BC), Mongols (1227), British (1838-1919), and Russians (1979-1988), among others, destroyed and/or displaced portions of the Afghan population. However, these major invasions also influenced gem exploration and production, as gems were sought to trade for weapons. In addition, throughout history, Afghan mining areas have been the objects of tribal wars and banditry (see, e.g., Wood, 1841). In 1992, the senior author experienced nightly rocket attacks when he visited the ruby mining area.

The Jegdalek mines have been worked for more than 700 years. During the 1200s, wealthy Muhammadan merchants sold rubies to Kublai Khan and other famous historical fig- 


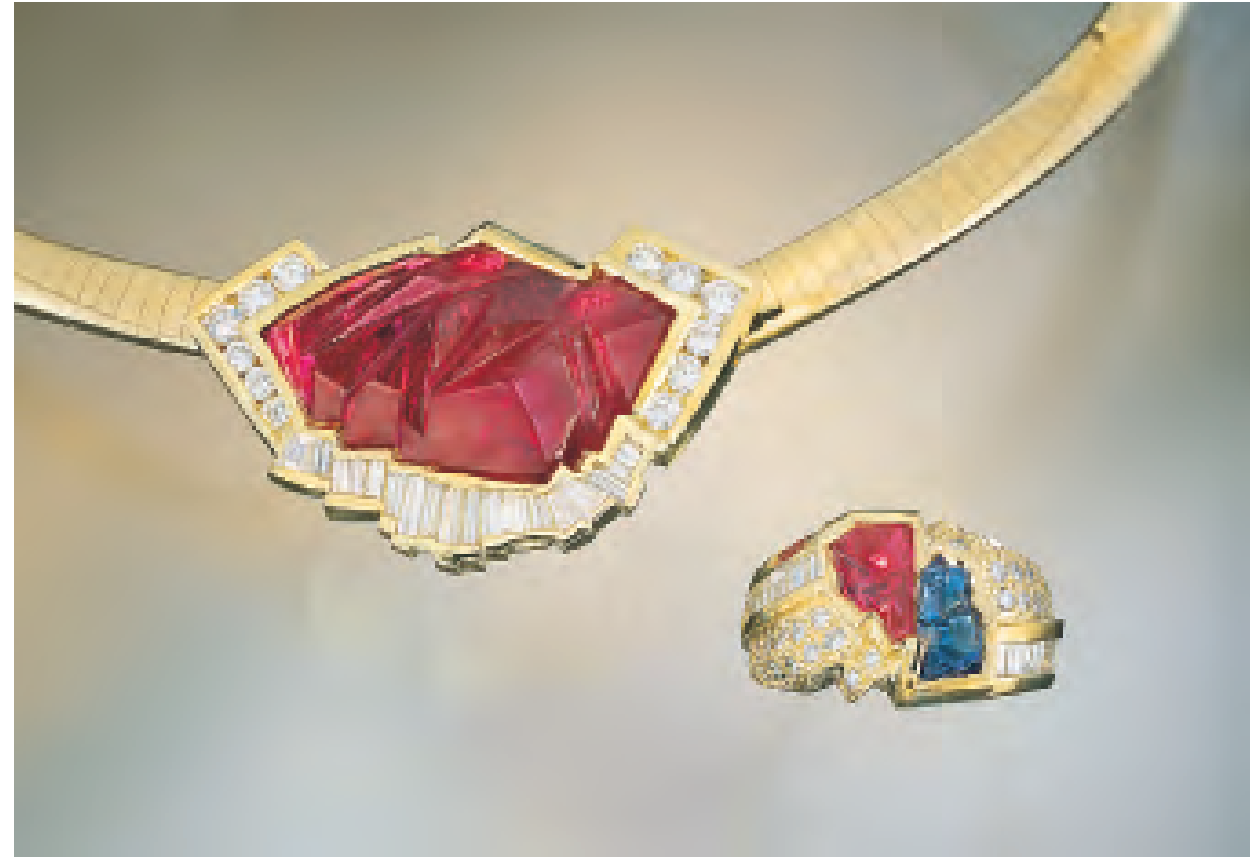

Figure 1. Although the Jegdalek region of Aghanistan has produced ruby and sapphire for more than 700 years, relatively little is known about these deposits. The 32.22 ct ruby in this $18 \mathrm{~K}$ gold pendant is from Jegdalek, as are the $0.94 \mathrm{ct}$ ruby and $1.31 \mathrm{ct}$ sapphire in the ring. The stones were carved by Bart Curren in the Glyptic Illusion style, and the jewelry was manufactured by Gregg Crawford; ring courtesy of Jewelry Box Antiques, Kansas City, Missouri. Photo (C) Harold «) Erica Van Pelt.

ures. These merchants reportedly could tell the difference between ruby and spinel (Bretschneider, 1887). For most of the last 100 years, the mines were owned and operated sporadically by the Afghan government. Shortly after the 1979 invasion, the Soviets ran the Jegdalek mines for five to six months. Today, they are exploited solely by local tribal people year-round.

\section{LOCATION AND ACCESS}

The Jegdalek mines are located approximately 60

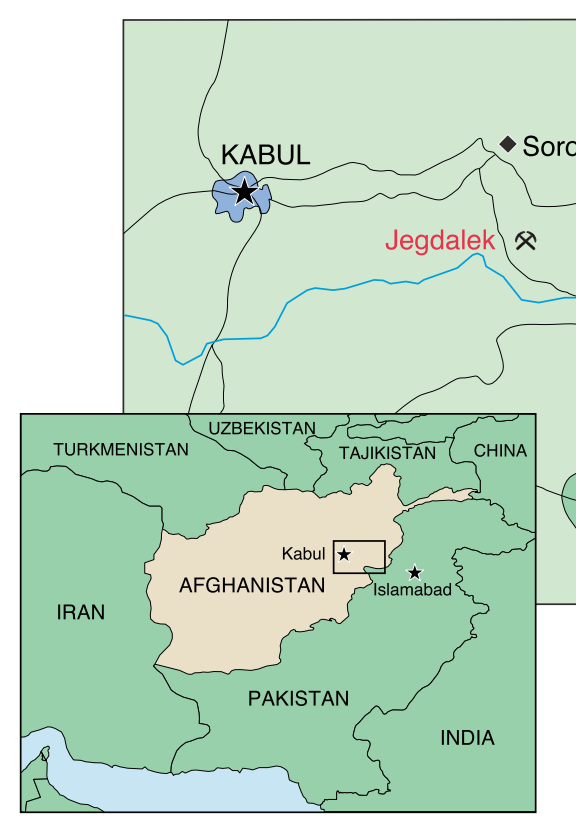

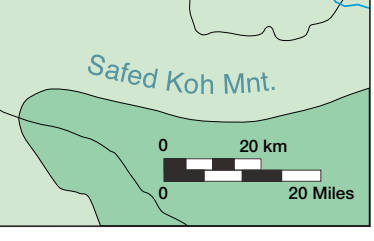

Figure 2. Historically, there was confusion over the location of the ruby deposits in Afghanistan, since places, names, and transliterations were gleaned from historical documents. Today, we know that the Jegdalek mining area is found in the southern portion of the Sorobi region, $60 \mathrm{~km}$ (37 miles) east of Kabul. The mines can be reached by vehicle from Kabul in about four to six hours. 


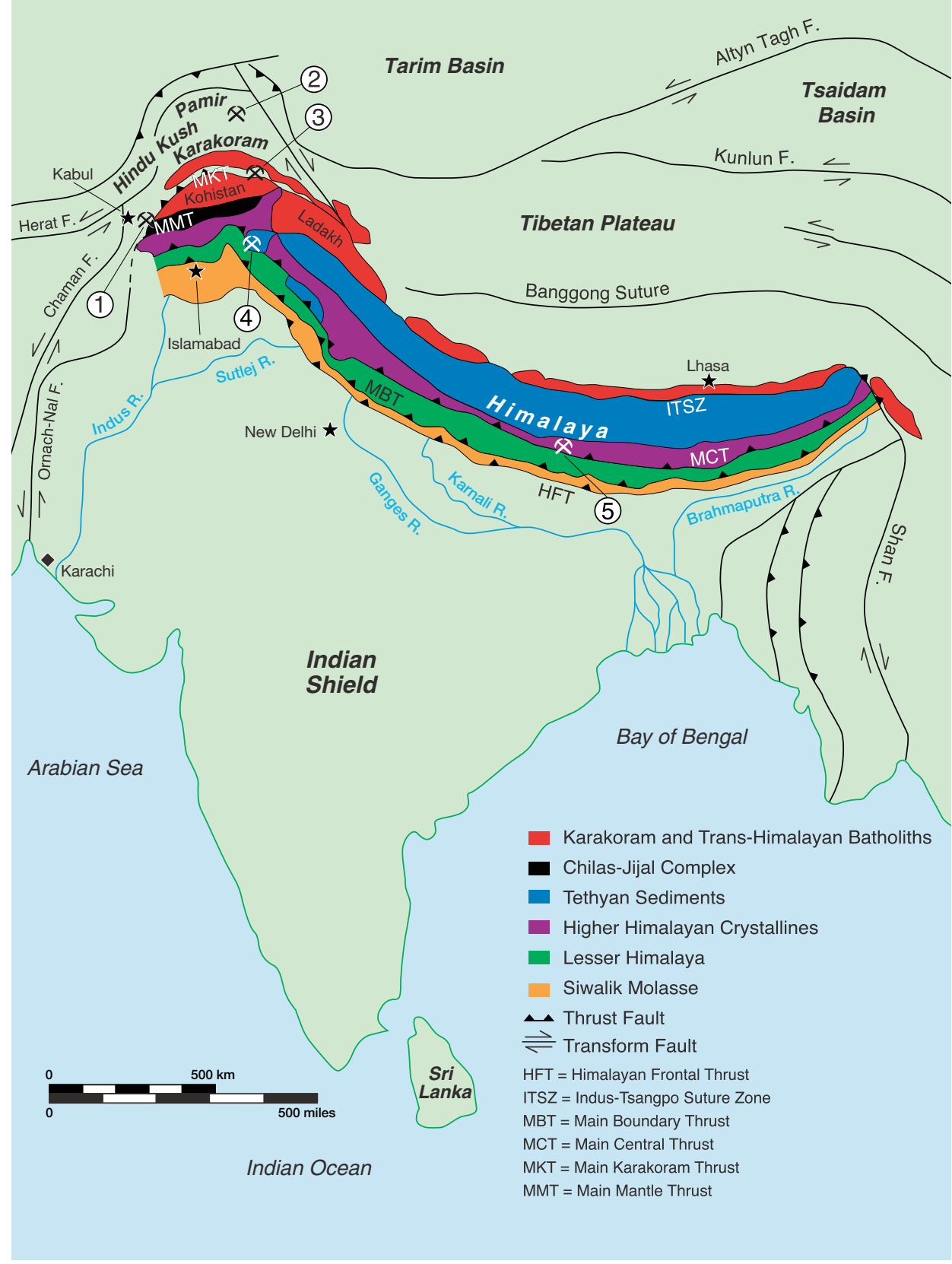

Figure 3. In South Asia, several marble-hosted ruby deposits are found within the continental collision zone between the Asian and Indian plates, including (1) Jegdalek; (2) Tajikistan; (3) Hunza, Pakistan; (4) Azad Kashmir; and (5) Nepal. Geology after Sorkhabi and Stump (1993); HFT = Himalayan Frontal Thrust, $I T S Z=$ Indus-Tsangpo Suture Zone, $M B T=$ Main Boundary Thrust, $M C T=$ Main Central Thrust, MKT = Main Karakoram Thrust, and MMT = Main Mantle Thrust.

Indian plates (figure 3), in a regional geologic setting similar to that of other ruby deposits in South Asia (i.e., Tajikistan [Smith, 1998]; Hunza, Pakistan [Gübelin, 1982]; Azad Kashmir [Kane, 1997]; and Nepal [Smith et al., 1997]). These deposits are hosted by metamorphosed limestones (marbles) that were originally deposited along the margins of one or both of the two plates. Although the age of ruby formation at these deposits is unknown, their spatial association suggests that they are related to the regional metamorphismand in some cases, the granitic magmatism-that accompanied the continental collision. The major collision between South Asia and the Indian subcontinent is estimated to have taken place 55-66 million years [m.y.] ago, although it may have begun as recently as $40 \mathrm{~m}$.y. ago (Powell and Conaghan, 1973). Still ongoing today, the collision resulted in the formation of the Himalaya, Karakoram, Hindu Kush, and Pamir mountain ranges (again, see figure 3).

As stated by Kazmi (1989), three distinct geotectonic domains or terranes are recognized in Pakistan and the adjacent regions of Iran and Afghanistan. From south to north, they are (1) southern or Gondwanic, (2) central or Tethyan, and (3) northern or Eurasian. The Jegdalek deposits lie within the central (Tethyan) terrane, which is a complex assemblage of ophiolitic rocks, geosynclinal sediments, island arcs, and micro-continents that probably collided with the southern edge of Eurasia in the early Jurassic. 


\section{LOCAL GEOLOGY AND OCCURRENCE OF RUBY AND SAPPHIRE}

The geology of the Jegdalek area has been described by Griesbach (1886, 1892), Barlow (1915), Orlov et al. (1974), and Rossovsky (1980). The rocks at the Jegdalek deposit are composed of interstratified Proterozoic gneisses and marbles (Nuristan series) that strike east-west. According to Rossovsky (1980), the marble is approximately 1,550-1,970 m.y. old.

The marble horizons range from $0.5 \mathrm{~m}$ up to 200-300 m (1.5 to 650-990 feet) thick and from several hundred meters to $7-8 \mathrm{~km}$ (4-5 miles) long (see, e.g., figure 4). The marbles are essentially pure calcite, with small amounts of magnesium impurities (0.68-4.78 wt.\% MgO). The associated gneisses are composed of kyanite-amphibole-pyroxene, pyroxene-biotite, biotite-amphibole, and other assemblages. The gneisses and marbles are intruded by numerous dikes of granite and desilicated pegmatites of the Oligocene-age Laghman complex (about 30 m.y. old; Debon et al., 1987).

The Jegdalek deposit probably formed by regional metamorphism of the marble and gneiss, with local contact metasomatic effects from the intruded granitic rocks. The aluminum, magnesium, and chromium necessary for the development of ruby and associated minerals were likely present within the host marbles as impurities (e.g., clay minerals) that were concentrated as a result of chemical weathering before the marbles were metamorphosed (see, e.g., Okrusch et al., 1976).

Ruby and sapphire are mined from two separate zones of mineralized marble-north and southwhich are separated from each other by a maximum of $600-800 \mathrm{~m}$, and joined in the west. The vertical extent of the corundum mineralization is more than $400 \mathrm{~m}$. Characteristic of the ruby-bearing marble is its coarse grain size. Ruby occurs in irregularly shaped lenses, rarely more than $2-3 \mathrm{~cm}$ wide, that are oriented lengthwise within individual horizons and beds of marble (Orlov et al., 1974).

\section{MINING METHODS}

In 1886, Griesbach wrote that there were about 300 men extracting rubies with hammer and chisel in the Jegdalek region. The senior author witnessed a similar mining situation in 1992, 1996, and 1998. Small-scale mining methods are used throughout the region. The gem-bearing marble is broken up with hammers, picks, prybars (figure 5), and, in a few cases, pneumatic drills (figure 6) and

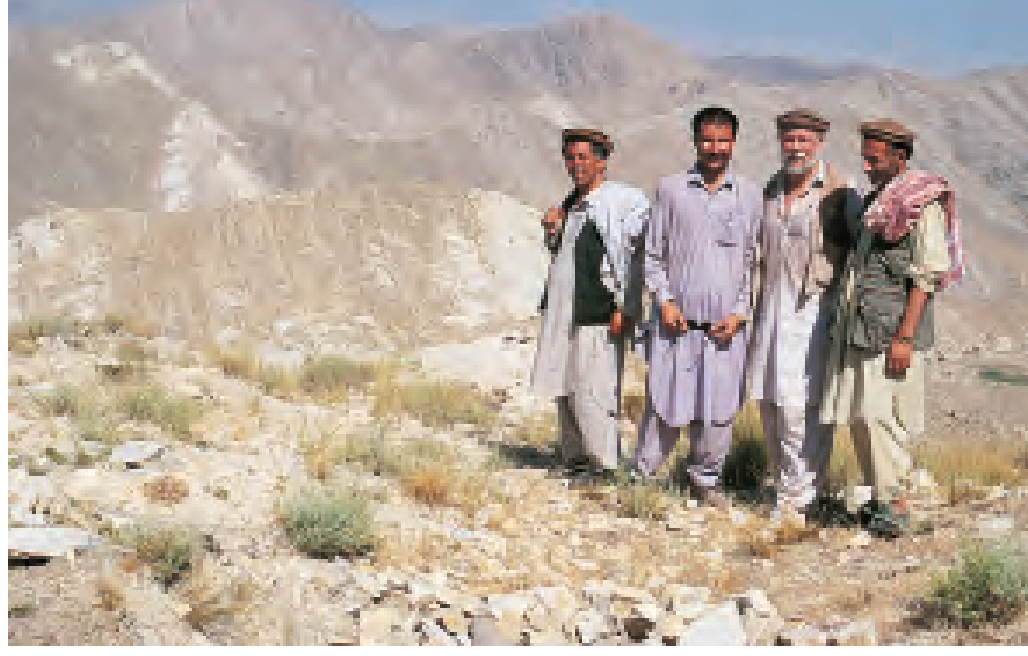

Figure 4. The senior author and miners are shown near the Jegdalek mining area. Several mine workings are visible along the mineralized marble belt that stretches eastward in the distance. Photo by Khudai Nazar Akbari.

dynamite. The broken rock is lifted from the mine pits (see figure 7) by a simple pulley system. Some of this material is stacked nearby to form rudimentary shelters (figure 8). Within these shelters, the gem-quality ruby and sapphire crystals are separated from the marble for cutting.

About 20 mines at Jegdalek have been named, and there are many small unnamed diggings. Today, approximately 400 miners are active. Most work in

Figure 5. Workers remove marble with prybars to uncover the gem corundum at Jegdalek. Most of the mining techniques used today are the same as those reported by Griesbach in 1892. Photo by Gary Bowersox.

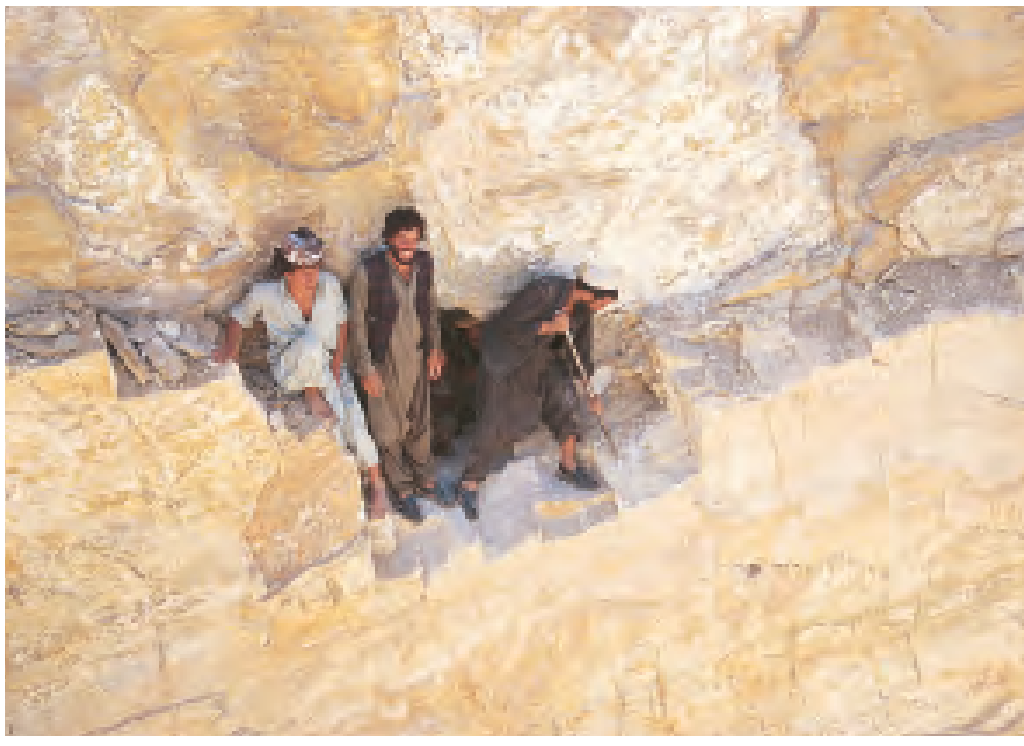


microscopic examination.) The polished samples (11 faceted stones and 26 cabochons, ranging from 0.51 to $16.50 \mathrm{ct}$ ) were cut from this material under the senior author's supervision. Also included in this study were numerous rough crystals, some of which were embedded in the marble host rock. This collection represented the full range of colors (tone and saturation, as well as hue) that the senior author has observed in ruby and sapphire from Jegdalek. On the basis of color, we defined three general groups: fancy-color sapphire (9), blue sapphire (1), and ruby (27).

We used standard gemological instruments to record the refractive indices, birefringence, optic character, pleochroism, optical absorption spectra (desk-model spectroscope), and reaction to longand short-wave ultraviolet radiation $(365 \mathrm{~nm}$ and $254 \mathrm{~nm}$, respectively) on the 37 fashioned samples; specific gravity was determined hydrostatically. The internal features of all samples were studied with a binocular microscope and fiber-optic and other lighting techniques.

We used a Perkin Elmer Lambda 19 spectrophotometer, with a beam condenser and polarizing filters, for polarized spectroscopy in the UV-visible through near-infrared region (between 280 and 880 $\mathrm{nm})$ on 11 samples. Infrared spectra were collected on 10 of the higher-quality fashioned samples with a Pye-Unicam Fourier-transform (FTIR) 9624 spectrometer in the region between 400 and $6000 \mathrm{~cm}^{-1}$; a diffuse reflectance unit was used for sample measurement. Energy-dispersive X-ray fluorescence (EDXRF) chemical analyses were performed on all 37 fashioned samples using a Spectrace TN5000 system, with a proprietary program specially developed for the Gübelin Gem Lab by Prof. W. B. Stern for the semi-quantitative analysis of corundum. This software uses chemically pure element standards and three sets of operating conditions that focus on light, medium, and heavy elements, so that the measurements of trace elements can be interpreted to three decimal places; a beam condenser was used to measure small areas or zones of a stone. More extensive trace-element data were obtained for a medium-red ruby by means of inductively coupled plasma-atomic emission spectrometry (ICP-AES) at the U.S. Geological Survey in Denver, Colorado. The analysis was done by P. H. Briggs using a Thermo Jarrell Ash Model 1160 instrument, with an argon plasma generated at 1,250 W; $200 \mathrm{mg}$ of sample was dissolved by the hydrogen peroxide sinter method.

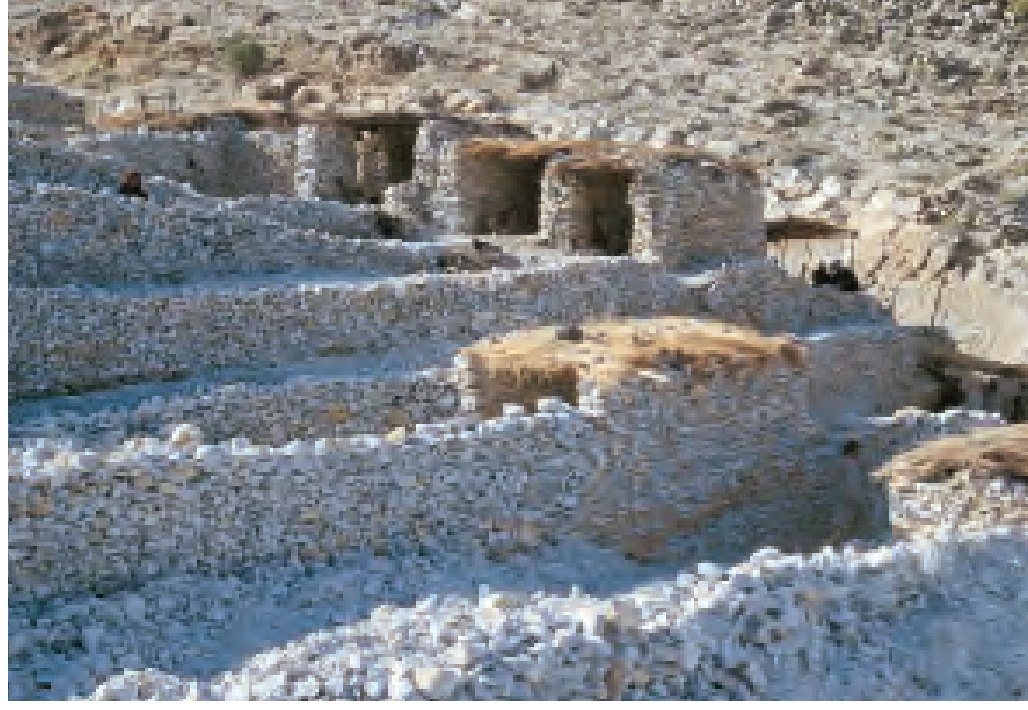

Figure 8. Marble from the trenches is used to build shelters for the miners, where the corundum is sorted. Working conditions are better than in other mines in Afghanistan, as the ruby and sapphire mines are lower in altitude and accessible all year. Photo by Gary Bowersox.

To analyze the internal growth structures of all the semitransparent to transparent polished stones, one of the authors (CS) used a horizontal microscope, a specially designed stone holder, and a

Figure 9. Fine mineral specimens, such as this ruby in marble matrix, are occasionally produced from the Jegdalek mines. The larger crystal shown here is approximately $1 \mathrm{~cm}$ high. Courtesy of William Larson; photo by Jeff Scovil.

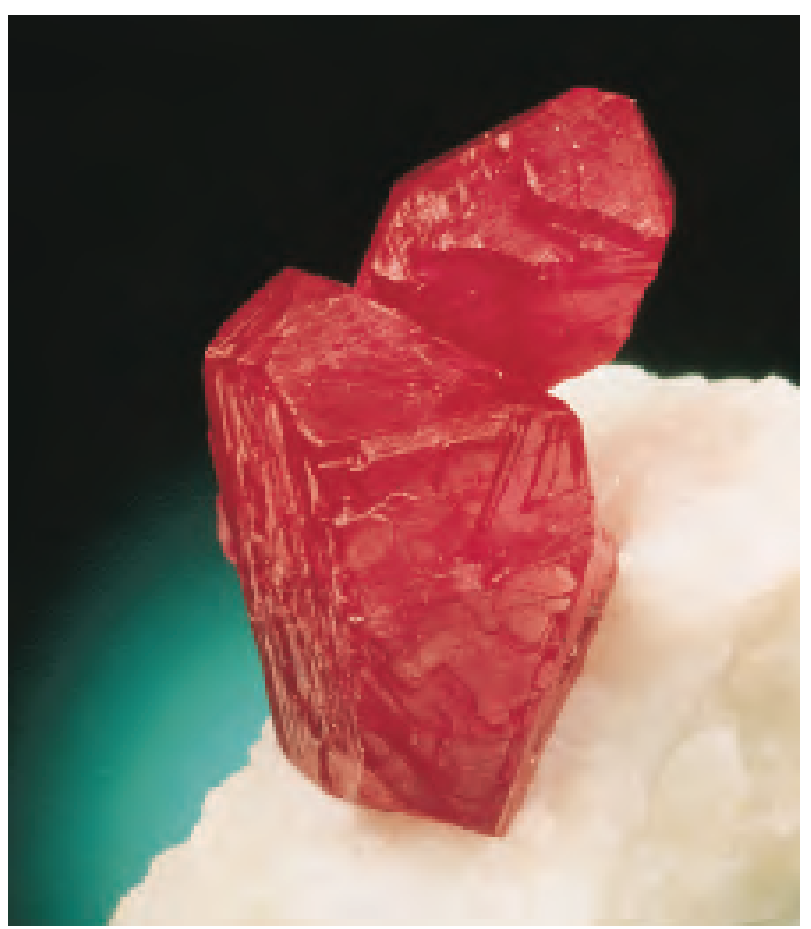



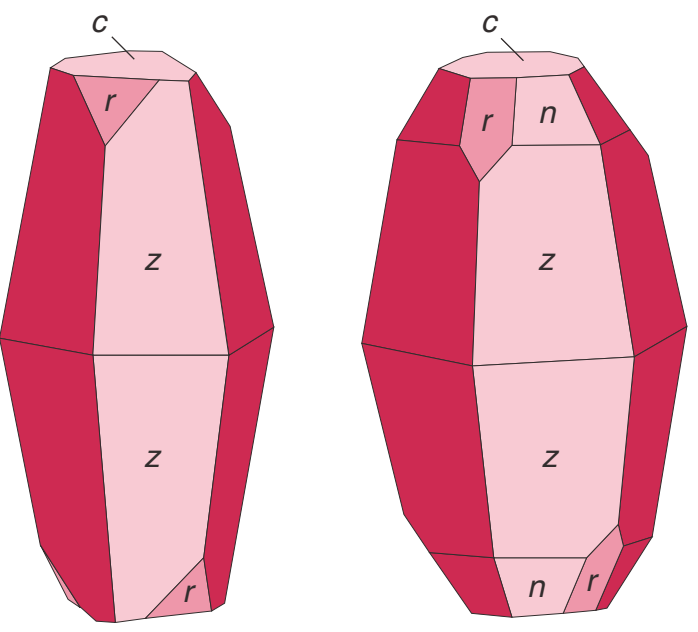

Figure 10. Two crystal habits are most typical in the rubies and sapphires from Jegdalek. The primary crystal form is dominated by dipyramidal z

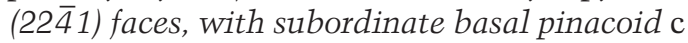
(0001) and positive rhombohedral r (1011) faces. This crystal form was also modified by subordinate

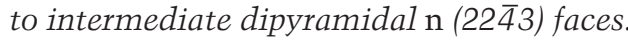

mini-goniometer attached to one of the oculars on the microscope, employing the methods described by Schmetzer (1986a and b), Kiefert and Schmetzer (1991), and Smith (1996). For the identification of most mineral inclusions, we used a Renishaw 2000 laser Raman microspectrometer, with an argon

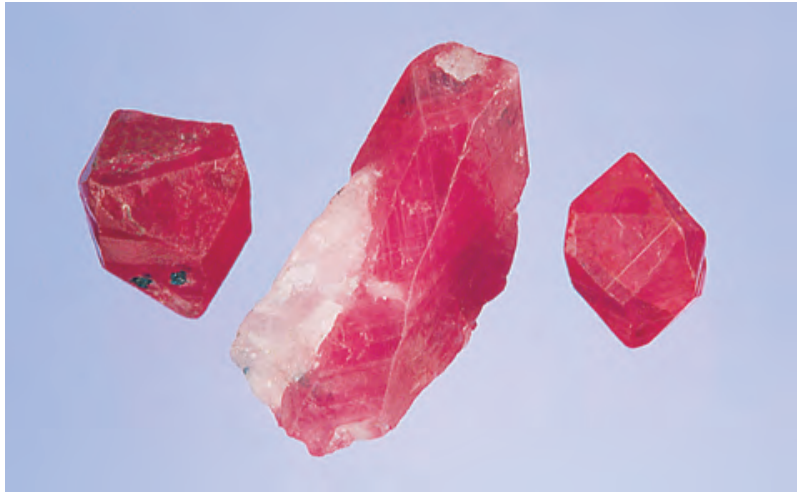

Figure 11. These three ruby specimens show the appearance of corundum crystals from Jegdalek. The two smaller crystals are typical, whereas the longer crystal in the middle has relatively large pyramidal faces. Two sets of twinning lines parallel to $\mathrm{r}\{10 \overline{1} 1\}$ are also visible in the largest crystal, which measures $2.0 \mathrm{~cm}$ long. Photo by Maha DeMaggio.

laser source $(514.5 \mathrm{~nm})$, in the spectral range between 100 and $2000 \mathrm{~cm}^{-1}$; other mineral inclusions were identified by X-ray diffraction analysis.

\section{RESULTS}

Crystal Morphology. Corundum from Jegdalek is typically subhedral, although some attractive euhedral crystals are found (figure 9; see also the cover of the Summer 1998 issue of Gems \& Gemology). The smaller crystals $(<2 \mathrm{ct})$ tend to be better formed, with

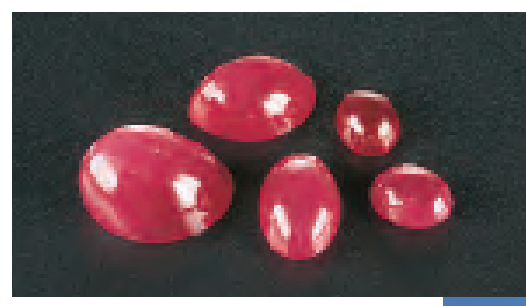

Figure 12. Cabochons of ruby and pink to pinkish violet sapphire from Jegdalek are cut in a range of colors, including some

bicolored stones. These samples (3.38-6.28 ct) formed a portion of those examined for this study. The cabochons in the inset (3.12-15.51 ct) show the typical "pure" red color of Jegdalek rubies. Photos by Maha DeMaggio.

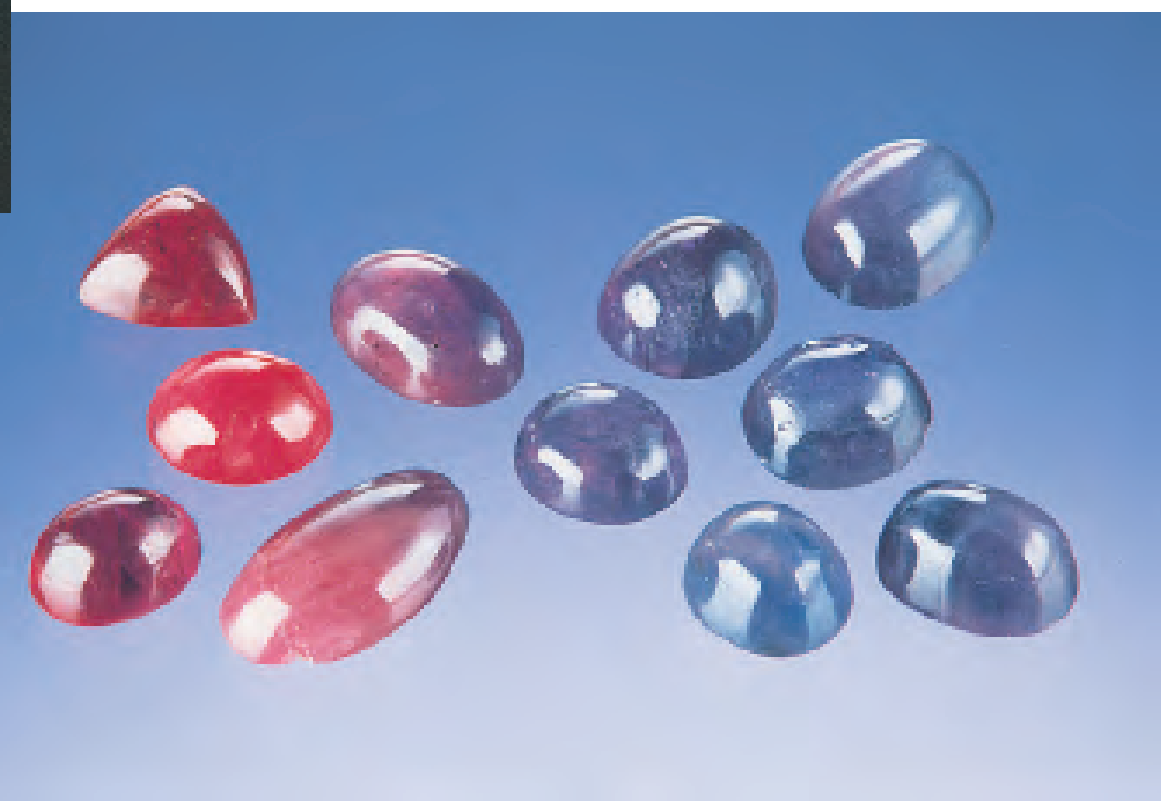




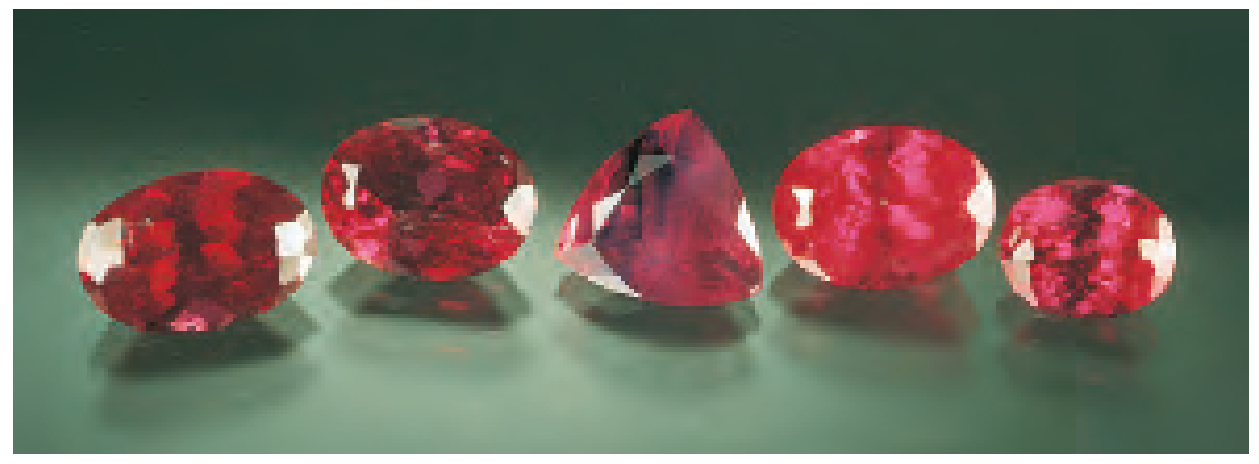

Figure 13. These faceted rubies and pink sapphires from Jegdalek weigh $0.68-1.25 \mathrm{ct}$. Photo by Jeff Scovil.

distinct crystal faces and sharp edges, whereas the external crystal forms of the larger crystals tend to be more heavily modified. Typically, there is little or no evidence of natural etching on the crystal faces. Two primary forms dominate the morphology of the Jegdalek corundum (figure 10; see also figure 11). Both consist of dipyramidal crystal habits composed of larger, dominant hexagonal dipyramidal $z(22 \overline{4} 1)$ faces and smaller, subordinate basal pinacoid $c(0001)$ and positive rhombohedral $r(10 \overline{1} 1)$ faces. In the second primary form, the basic crystal habit $c, r, z$ is

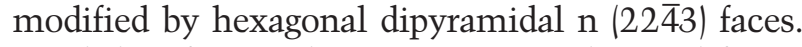
Much less frequently, we encountered crystal forms with dominant hexagonal dipyramidal $\omega$ (14 $14 \overline{28} 3$ ) faces and subordinate $c, r$, and occasionally $n$ faces.

Gemological Characteristics. Visual Appearance. The fancy-color sapphire samples commonly showed both blue and red/pink color zones, so the overall appearance ranged from bluish violet, through violet and purple, to reddish purple (see, e.g., figure 12). We examined only one sample of a "pure" blue sapphire (mounted in the ring shown in figure 1), which is consistent with the very small amount of cuttable blue sapphire seen at the mines. The rubies ranged from "pure" red to purplish red (see, e.g., figures 12 [inset] and 13); some also had blue zones (see Growth Characteristics below). Most of the fancy-color sapphires and rubies were medium to dark in tone, with variable weak to strong saturation. For the most part, the faceted stones were semitransparent to transparent, and the cabochons were semitransparent to translucent. Several of the samples also had translucent whitish areas, which microscopic examination indicated were remnants of the marble host rock (figure 14).

Physical Properties. The standard gemological properties (table 1) were consistent with corundum in general (see, e.g., Liddicoat, 1989; Webster, 1994) and with the rubies and fancy-color sapphires from Jegdalek described previously (e.g., Hughes, 1994).
Reaction to Ultraviolet Radiation. A range of fluorescence responses was noted according to the different colors. The fancy-color sapphires typically revealed a faint to medium red or orange-red fluorescence to long-wave UV. The distribution of the fluorescence was homogeneous in some samples and uneven in others. In addition, a few samples revealed zones of orange fluorescence. A chalky blue fluorescence also was noted in areas of those samples that still had some of the marble matrix. Similar but weaker reactions were observed with short-wave UV; a few of the stones were inert. The blue sapphire sample was inert to both long- and short-wave UV.

The rubies typically fluoresced an evenly distributed medium to strong red to long-wave UV, and faint to medium red to short-wave UV. The few

Figure 14. Translucent white masses were frequently encountered at the surface of the polished corundums in this study. These remnants of the marble host rock were typically composed of calcite, sometimes with apatite and/or margarite. Photomicrograph by Christopher $P$. Smith; magnified 25x.

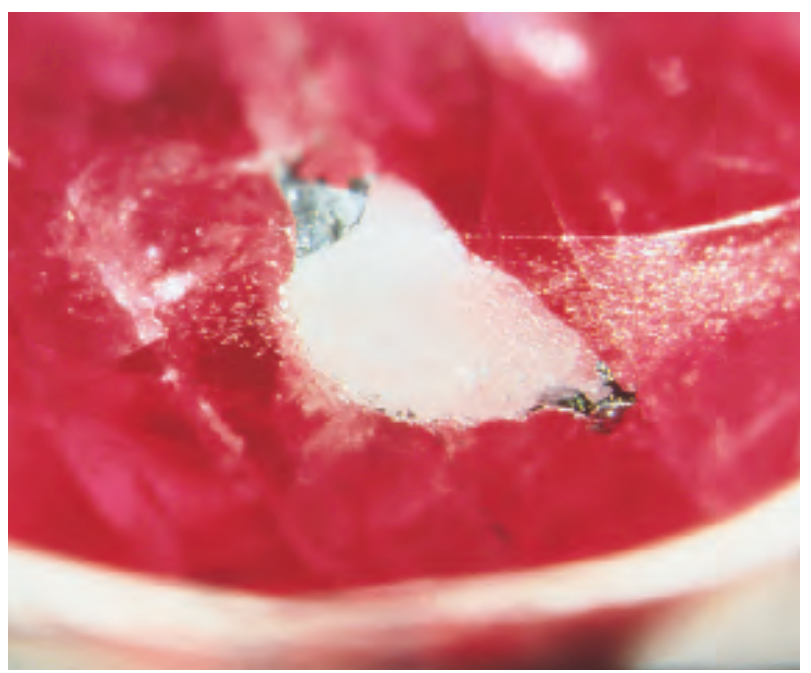


TABLE 1. Gemological characteristics of the rubies and sapphires from Jegdalek, Afghanistan.

\begin{tabular}{|c|c|c|c|}
\hline Property & $\begin{array}{l}\text { Rubies } \\
(9)^{a}\end{array}$ & $\begin{array}{l}\text { Fancy-color } \\
\text { sapphires (27) }\end{array}$ & $\begin{array}{c}\text { Blue } \\
\text { sapphire (1) }\end{array}$ \\
\hline Color & $\begin{array}{l}\text { Red to } \\
\text { purplish red }\end{array}$ & $\begin{array}{l}\text { Ranges from bluish } \\
\text { violet, through violet } \\
\text { and purple, to } \\
\text { reddish purple }\end{array}$ & Blue \\
\hline $\begin{array}{l}\text { Clarity } \\
\text { (all groups) }\end{array}$ & \multicolumn{3}{|c|}{$\begin{array}{l}\text { Very clean to heavily included; } \\
\text { most are moderately to heavily included }\end{array}$} \\
\hline $\begin{array}{l}\text { Refractive } \\
\text { index (all } \\
\text { groups) }\end{array}$ & \multicolumn{3}{|c|}{$\begin{array}{l}n_{\varepsilon}=1.760-1.762 \\
n_{\omega}=1.76-1.770 \\
n^{\prime}=1.76-1.77 \text { (spot) }\end{array}$} \\
\hline $\begin{array}{l}\text { Birefringence } \\
\text { (all groups) }\end{array}$ & \multicolumn{3}{|c|}{$0.008-0.009$} \\
\hline $\begin{array}{l}\text { Specific gravity } \\
\text { (all groups) }\end{array}$ & \multicolumn{3}{|c|}{$\begin{array}{c}\text { 3.97-3.99: } \\
\text { typical range } \\
3.73-3.96: \\
\text { contained carbonate impurities }\end{array}$} \\
\hline
\end{tabular}

\begin{tabular}{|c|c|c|c|}
\hline \multicolumn{4}{|l|}{ Pleochroism } \\
\hline $\begin{array}{l}\text { Parallel to } \\
\text { the } c \text { axis }\end{array}$ & $\begin{array}{l}\text { Reddish } \\
\text { orange to } \\
\text { orangy red }\end{array}$ & $\begin{array}{l}\text { Mostly greenish blue, } \\
\text { or bluish violet to } \\
\text { purple }\end{array}$ & $\begin{array}{l}\text { Greenish } \\
\text { blue to } \\
\text { blue }\end{array}$ \\
\hline $\begin{array}{l}\text { Perpendi- } \\
\text { cular to the } \\
\text { c-axis }\end{array}$ & $\begin{array}{l}\text { Red-purple } \\
\text { to purplish } \\
\text { red }\end{array}$ & $\begin{array}{l}\text { Mostly violet to } \\
\text { purple, or purple-red } \\
\text { to orangy red }\end{array}$ & Violet \\
\hline \multicolumn{4}{|l|}{$\begin{array}{l}\text { UV } \\
\text { fluorescence }^{\mathrm{b}}\end{array}$} \\
\hline Long-wave & $\begin{array}{l}\text { Medium to strong } \\
\text { red (blue zones } \\
\text { are inert) }\end{array}$ & $\begin{array}{l}\text { Faint to medium red } \\
\text { or orange-red } \\
\text { (+orange zones) }\end{array}$ & Inert \\
\hline Short-wave & $\begin{array}{l}\text { Faint to medium } \\
\text { red (blue zones } \\
\text { are inert) }\end{array}$ & $\begin{array}{l}\text { Inert to very faint red } \\
\text { (+orange zones) }\end{array}$ & Inert \\
\hline $\begin{array}{l}\text { Inclusions and } \\
\text { internal growth } \\
\text { features (all } \\
\text { groups) }\end{array}$ & \multicolumn{3}{|c|}{$\begin{array}{l}\text { Numerous partially healed and nonhealed fracture planes } \\
\text { with a frosted texture, lamellar twinning, color zoning, a variety } \\
\text { of flake-like and stringer inclusion patterns, brush-stroke } \\
\text { or nebulous inclusion patterns, very fine grained bluish white } \\
\text { clouds, weak to moderate growth structures, negative crystals } \\
\text { with tiny graphite platelets, clouds of short rutile needles, } \\
\text { and crystalline inclusions of: mica, apatite, calcite, zircon, } \\
\text { rutile, graphite, boehmite, pyrite, marcasite, and pyrrhotite. }\end{array}$} \\
\hline $\begin{array}{l}\text { Visible } \quad \text { G } \\
\text { absorption } \\
\text { spectrum } \\
\qquad 525-58\end{array}$ & $\begin{array}{r}\text { eneral absorption up to } \\
468 \mathrm{~nm} \text { (sha } \\
475 \mathrm{~nm} \text { (sharp, w } \\
476 \mathrm{~nm} \text { (sha } \\
5 \mathrm{~nm} \text { (broad band, wic } \\
659 \mathrm{~nm} \text { (fai } \\
668 \mathrm{~nm} \text { (fai } \\
675 \mathrm{~nm} \text { (very faint, } \\
692 \mathrm{~nm} \text { (sha } \\
694 \mathrm{~nm} \text { (sha }\end{array}$ & $\begin{array}{l}\text { approximately } 450 \mathrm{~nm} \\
\text { rp, narrow) } \\
\text { eak to moderate) } \\
\text { rp, narrow) } \\
\text { th dependent on Cr conte } \\
\text { tt, narrow) } \\
\text { tt, narrow) } \\
\text { arrow when present) } \\
\text { rp, narrow) } \\
\text { rp, narrow) }\end{array}$ & $\begin{array}{l}\text { Spectrum } \\
\text { not taken }\end{array}$ \\
\hline
\end{tabular}

a Number of samples shown in parentheses.

${ }^{b}$ Several stones additionally revealed a distinct chalky blue fluorescence to both long- and short-wave UV, due to the presence of marble matrix at the surface. samples with distinct blue color zones showed no fluorescence in those zones. Again, a chalky blue fluorescence was noted with both long- and shortwave UV in those samples that contained remnants of the marble matrix.

Specific Gravity. In general, the specific gravity of "pure" corundum is relatively constant, between 3.98 and 4.01. Twenty-eight of the fashioned samples had S.G. values near this range, between 3.97 and 3.99. The remaining nine samples had lower S.G. values, which were due to the presence of carbonate, either as mineral inclusions or as large areas of marble matrix that were not fully removed during cutting. Seven of these samples had S.G.'s between 3.91 and 3.96, whereas the two samples with the largest masses of marble matrix had S.G.'s of 3.86 and 3.73 .

Growth Characteristics. Twinning. Most of the fancy-color sapphire and ruby samples revealed numerous lamellar twin planes parallel to two or three directions of the positive rhombohedron $r$ $(10 \overline{1} 1)$; these are partially responsible for the low transparency. The better-quality samples typically had only one dominant system of twin planes parallel to $r$, whereas others also had a minor secondary system. The blue sapphire was not twinned.

Internal Growth Structures. Because of the high degree of twinning - and, in many cases, large number of inclusions-we could not observe internal growth structures in any of the translucent and most of the semitransparent samples studied. In a few of the semitransparent samples, and all the transparent stones, we did note weak to moderate growth structures: straight and angular sequences of the dipyramidal crystal faces $z(22 \overline{4} 1)$ or $n(22 \overline{4} 3)$ and the positive rhombohedron $r(10 \overline{1} 1)$, as illustrated in figure 15 .

Color Zoning. We saw weak to distinct color zoning in many of our samples. The fancy-color sapphires typically had both blue and red/pink color zones. In this group, the two colors tended to blend, producing a rather even face-up coloration. In two of these samples, however, we noted narrow dark blue bands parallel to the positive rhombohedron $r$ (figure 16). The blue sapphire was homogeneous in color.

Most of the rubies were homogeneous in color. However, a few stones revealed adjacent red and pink zones, which followed the internal growth structures. Several of the samples in this group also displayed 


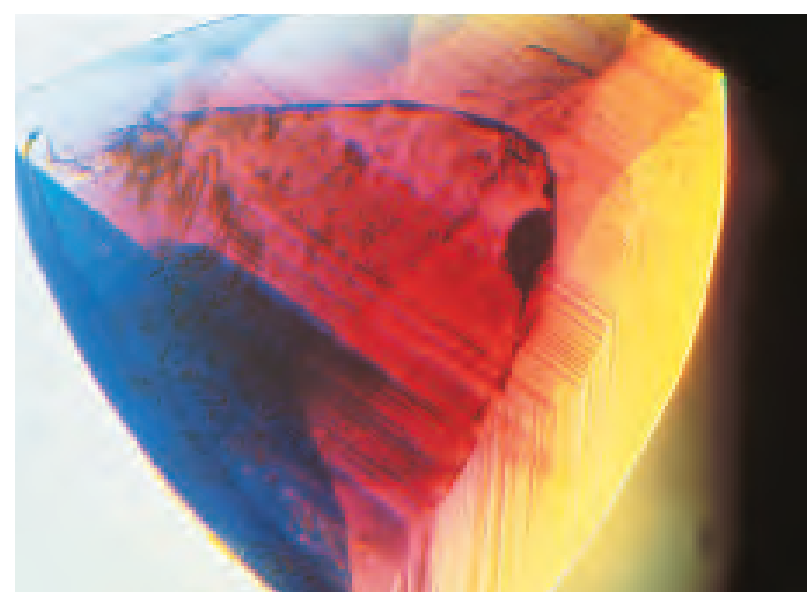

Figure 15. Weak to moderate planar and angular sequences of internal growth structures were noted in a few of the rubies from Jegdalek. These typically consisted of combinations of the dipyramids $\mathrm{z}$ or $\mathrm{n}$, as well as the positive rhombohedron r. In this sample, we see a combination of $\mathrm{z}$ growth planes. Photomicrograph by Christopher P. Smith; immersion, magnified 15x.

zones of dark to medium blue, which stood in stark contrast to the surrounding ruby (figure 17). For the most part, these distinct blue zones tended to occur parallel to the positive rhombohedron $r$, although they were also noted following the growth banding parallel to the dipyramidal planes $n$ and $z$ (figure 18).

In general, these blue color zones tended to form narrow bands, although they also were observed as larger areas. Occasionally we noted distinct geo-

Figure 17. Strong blue color zones were observed in many of the Jegdalek rubies. Also note the flake-like inclusions associated with the blue zones in this $1.19 \mathrm{ct} \mathrm{sample.} \mathrm{Photomicrograph}$ by Christopher P. Smith; magnified 25x.

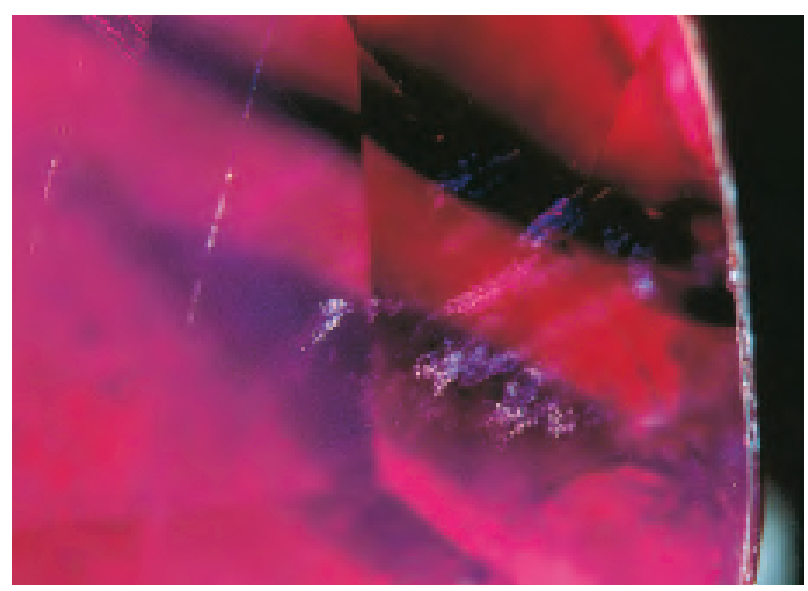

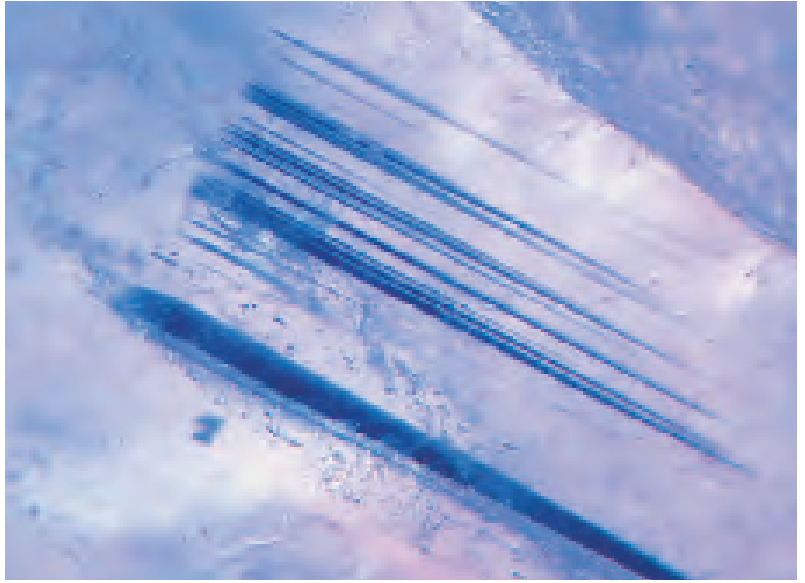

Figure 16. Sharply defined blue lamellar color zoning was seen in some of the corundum samples.

Photomicrograph by John I. Koivula; magnified 15×.

metric formations, which resulted from the blue coloration following a sequence of dipyramidal and rhombohedral growth planes.

Inclusions. Dense concentrations of partially healed and nonhealed fracture planes, in addition to numerous twin planes, were responsible for the reduced transparency of many of the samples in this study. Many of the partially healed fracture planes revealed a distinctly "frosted" texture (figure 19), and a few had an orange-to-brown epigenetic staining.

A variety of mineral inclusions were noted;

Figure 18. Typically the blue color zones corresponded to growth in certain crystallographic orientations - that is, along the $\mathrm{r}, \mathrm{n}$, and $\mathrm{z}$ faces. The large blue color zone in this sample follows two positive rhombohedral and two dipyramidal growth planes. Photomicrograph by Christopher P. Smith; immersion, magnified 20x.

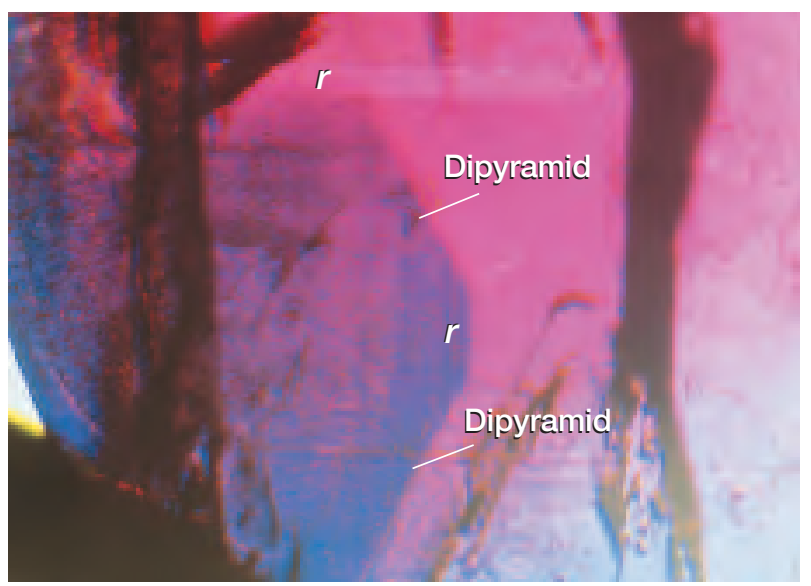




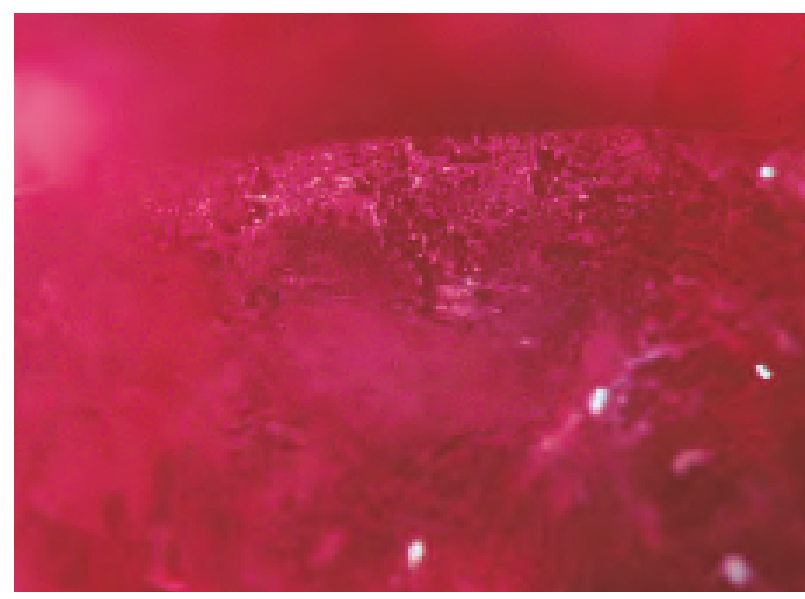

Figure 19. Most of the rubies and fancy-color sapphires in this study had a high concentration of partially healed fracture planes. One consistent feature of these planes was the distinctly "frosted" texture. Photomicrograph by Christopher P. Smith; magnified 50×.

transparent colorless to translucent white crystals of calcite were the most common (figure 20). Also present in some stones were transparent to translucent colorless crystals of apatite; most of these were rounded (figure 21), although some had a more prismatic habit. Some small transparent colorless rounded crystals proved to be zircon. Transparent colorless and translucent white masses at the surface of several polished samples were identified as calcite, apatite, margarite, or a combination of these

Figure 20. Common to most marble-type deposits of corundum, transparent colorless rounded forms of calcite were identified in a number of the rubies and fancy-color sapphires from Jegdalek. In this ruby, the calcite formed a cluster of inclusions in a nearly parallel formation. Photomicrograph by Christopher P. Smith; magnified 60x.

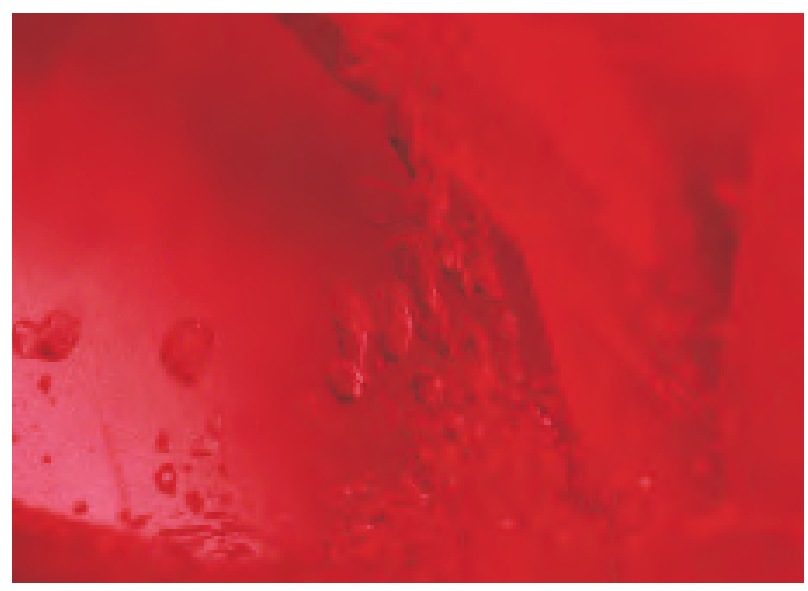

three (again, see figure 14). Analytical testing was required to make these distinctions.

Iron sulfide minerals, such as pyrite, marcasite, and pyrrhotite, were present along fracture and twin planes (figure 22), although they were also seen rarely as isolated grains or masses (figure 23). Graphite frequently was observed as solitary geometric platelets, as well as clustered in groups. In addition, tiny graphite scales were noted in many of the multi-phase negative crystals that composed the healed fracture planes (figure 24). Transparent brown platelets of mica were occasionally noted in close association with calcite crystals. Very dark orange to black crystals of rutile could be seen isolated or in close proximity to apatite crystals (again, see figure 21). Rarely, very fine iridescent needles of rutile were concentrated in patches (figure 25). One intriguing inclusion was a colorless prismatic crystal, which could not be conclusively identified.

Among the more interesting internal features seen in some of the samples were a variety of flakelike inclusions and stringers that were very fine in some instances and rather coarse in others (figure 26). Similar types of inclusions had a more "brushstroke" or "nebulous" patterning (figure 27). Observed in only a small number of samples was a very fine-grained bluish white zonal cloud that followed the development of the internal growth structures (figure 28).

Irregular "veins" of $\mathrm{AlO}(\mathrm{OH})$ (typically boehmite—see "Infrared Spectroscopy" below) were

Figure 21. Colorless, rounded, high-relief crystals of apatite and stubby, dark orange to black crystals of rutile were common inclusions in the Jegdalek corundum. Photomicrograph by John I. Koivula; magnified 20×.

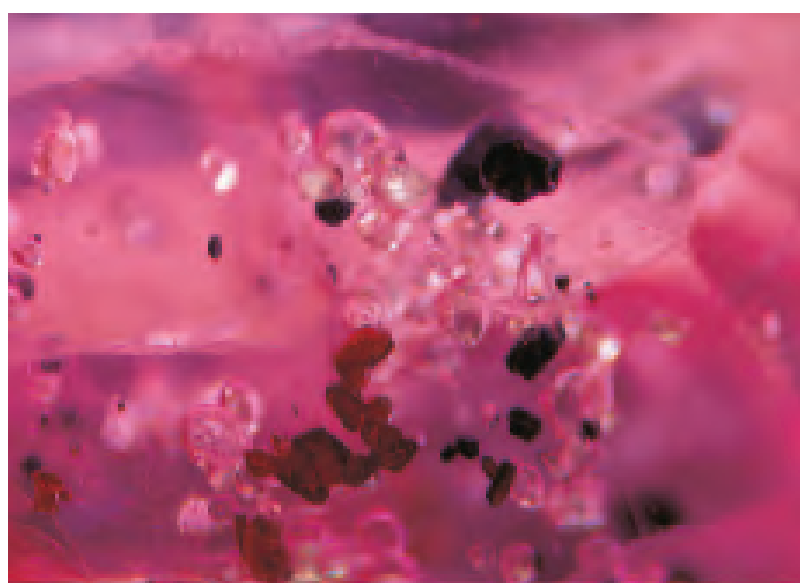



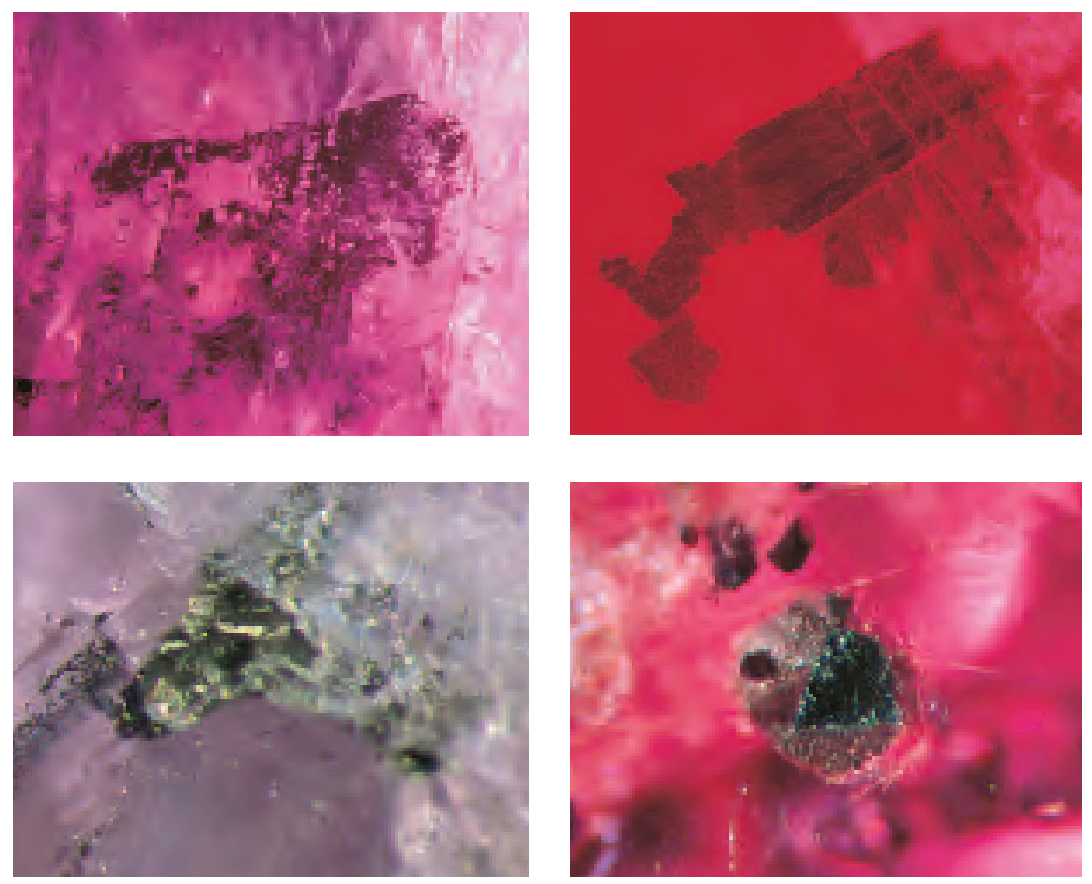

Figure 22. One distinctive inclusion feature in the rubies and fancycolor sapphires from Jegdalek consists of iron sulfide minerals such as pyrite, marcasite, and pyrrhotite that were present along healed fracture planes (left; magnified 20x) and parting planes (right; magnified 15x). Photomicrographs by Christopher P. Smith.

Figure 23. Pyrite formed irregular brassy masses in one of the sapphire samples (left); a surface-reaching grain of iron sulfide was also present in a ruby sample (right). Photomicrographs by John I. Koivula; both magnified 15x. also noted traversing several of the polished gems. In reflected light, the reduced luster of these veins, as compared to the higher luster of the host corundum (figure 29), could be mistaken for the glass-like fillings observed in heat-treated rubies. Such inclusions are the result of an alteration process, where a retrograde metamorphic reaction alters the corundum, in the presence of water, to an aluminum hydroxide (Haas, 1972). These alteration products also formed needle-like inclusions that coated the surface of "intersection tubules" created at the junction of two twin planes and were seen lining the twin planes.

Figure 24. Tiny graphite platelets were commonly found within isomorphic negative crystals. Photomicrograph by Christopher P. Smith; magnified $80 \times$.

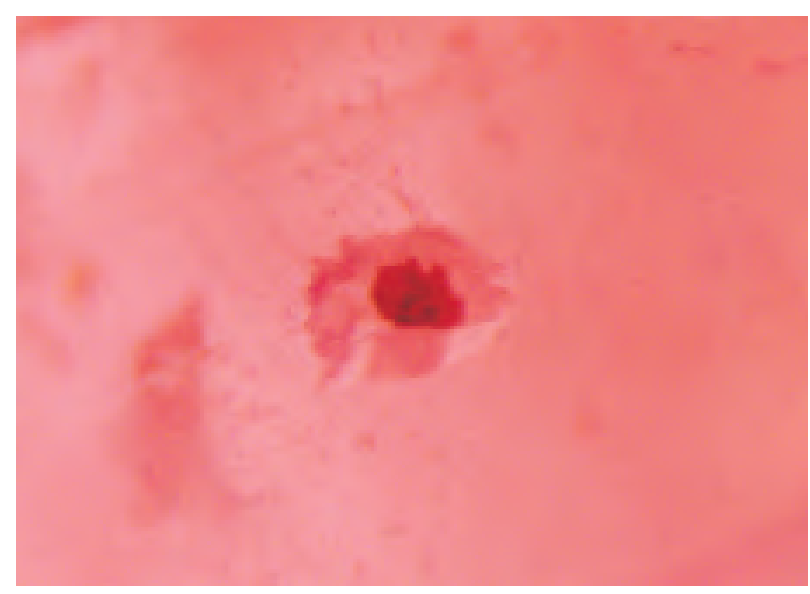

UV-Vis-NIR Spectroscopy. With a desk-model or handheld spectroscope, the following features were noted in the visible region for the fancy-color sapphires and rubies: general absorption up to approximately $450 \mathrm{~nm}$, a broad band at 525-585 nm, and sharp lines at 468, 475, 476, 692, and $694 \mathrm{~nm}$; faint lines were sometimes seen at 659, 668, and $675 \mathrm{~nm}$ (table 1). The UV-Vis-NIR polarized absorption

Figure 25. Rutile needles are not typical in rubies from Jegdalek, although very fine, short rutile needles were observed in two samples. Their appearance was markedly different from the long, iridescent rutile needles typically found in rubies from marble-type deposits, such as at Mogok, Myanmar. Photomicrograph by Christopher P. Smith; magnified 30x.

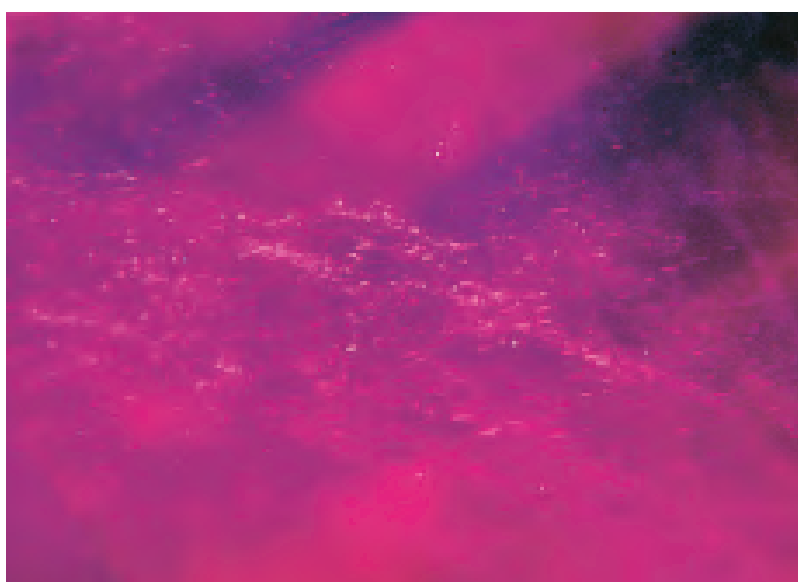




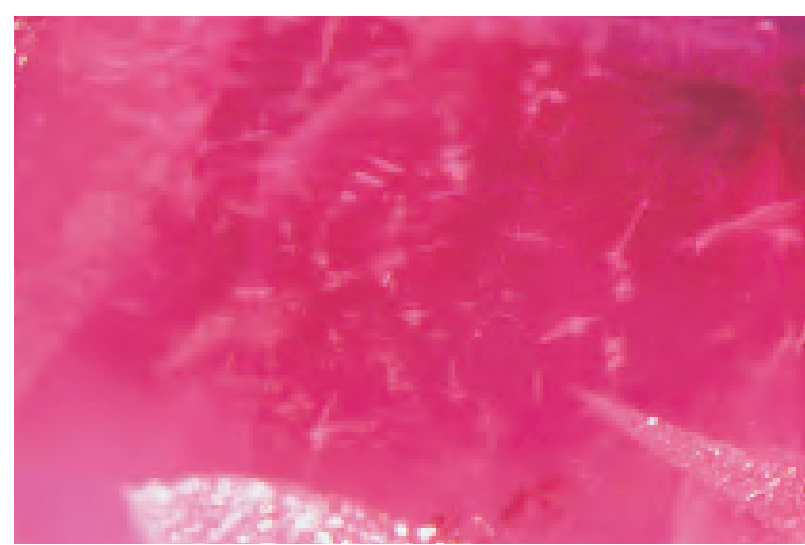

Figure 26. One of the more characteristic features of rubies from Jegdalek consists of flake-like inclusion patterns and stringers that were finely textured in some samples and coarser in others. Similar inclusion features may be found in rubies from Vietnam and Mong Hsu (Myanmar). Photomicrograph by Christopher P. Smith; magnified 35x.

spectra were dominated by $\mathrm{Cr}^{3+}$ absorption features that were weaker in those stones that were more purple to violet, and more intense in those that were purer red. A secondary absorption influence was seen as a result of the $\mathrm{Fe}^{2+} \leftrightarrow \mathrm{Ti}^{4+}$ intervalence charge transfer responsible for the blue color component in the violet stones. These features are characteristic of all natural and synthetic ruby and pink sapphire, regardless of origin.

Figure 28. Bluish white clouds followed the zonal growth structures in a small number of the Jegdalek samples. Such clouds may impart a kind of "sheen" to the stone, and have also been observed in rubies from Vietnam and Tajikistan. Photomicrograph by Christopher P. Smith; magnified 25x.

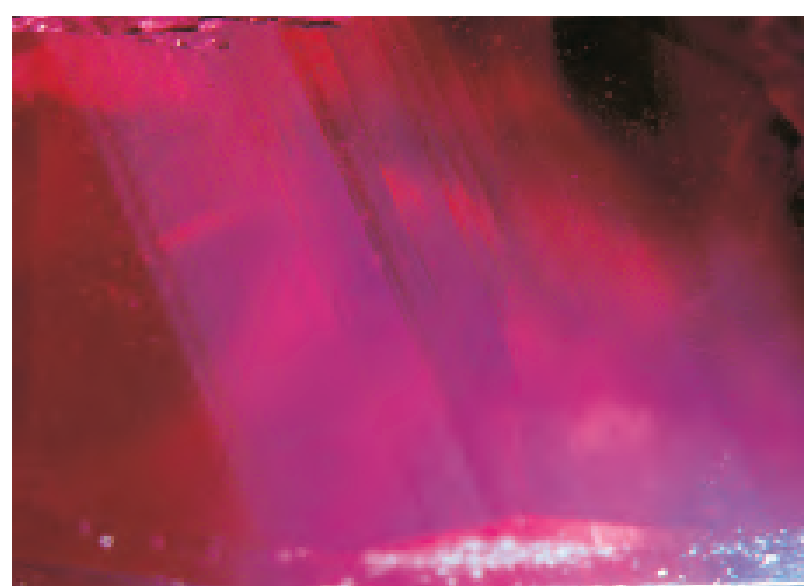

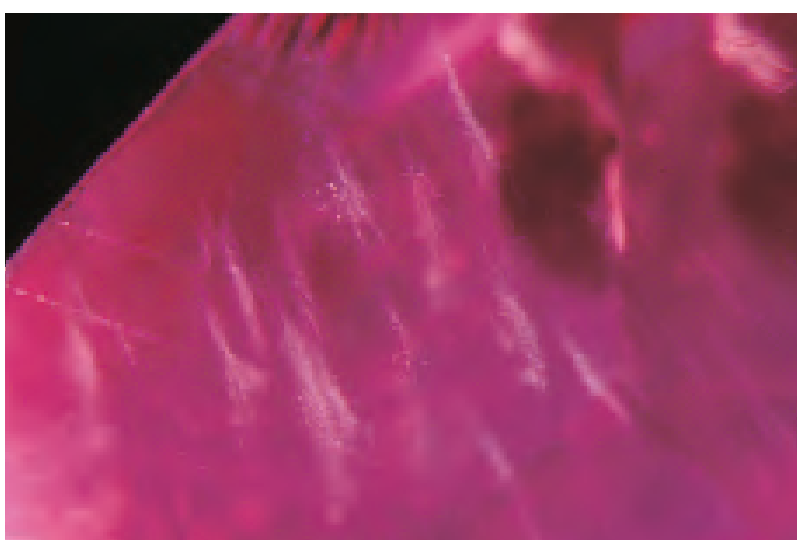

Figure 27. Other distinctive inclusion patterns showed a brush-stroke or more nebulous appearance. Photomicrograph by Christopher P. Smith; magnified $30 \times$.

Infrared Spectroscopy. In addition to the dominant absorption characteristics of corundum between approximately 400 and $1000 \mathrm{~cm}^{-1}$ (peak positions at about 760, 642, 602, and $450 \mathrm{~cm}^{-1}$; Wefers and Bell, 1972), the rubies and fancy-color sapphires in this study (none of which were heat treated) revealed a series of absorption bands in the $1900-4000 \mathrm{~cm}^{-1}$ region. The two most dominant bands were located at approximately $3320 \mathrm{~cm}^{-1}$ and $3085 \mathrm{~cm}^{-1}$, with an additional pair of weaker bands at approximately 2100 and

Figure 29. The reduced luster of a seam or vein of aluminum hydroxide (such as boehmite) visible on the surface of a ruby or sapphire from Jegdalek may at first resemble the glass-like residues present in many heat-treated rubies. With closer inspection, however, the inclusion features should clearly reveal the nonheated condition of such a stone. Photomicrograph by Christopher P. Smith; reflected light, magnified 25x.

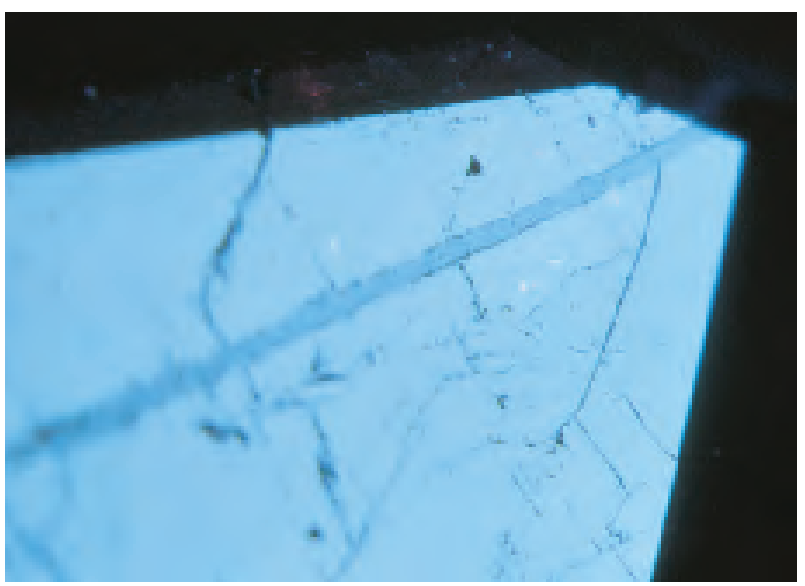


$1980 \mathrm{~cm}^{-1}$ (figure 30). These absorption bands are related to $\mathrm{OH}$-stretching frequencies and indicate the presence of the mineral boehmite (Farmer, 1974; Wefers and Misra, 1987). Several of the samples displayed such strong $\mathrm{AlO}(\mathrm{OH})$ absorption features that it was not possible to determine which aluminum hydroxide was present (i.e., boehmite or diaspore). However, not all samples had the $\mathrm{AlO}(\mathrm{OH})$-related bands. Absorption bands associated with mica and calcite were also recorded occasionally.

Chemical Composition. The most significant traceelement variations recorded were in chromium concentration (table 2); in both the fancy-color sapphires and rubies, $\mathrm{Cr}$ concentration correlated directly to depth of red to pink color in the area measured. The other color-causing transition metals, titanium and iron, were the next most significant trace elements recorded, followed by measurable amounts of vanadium and gallium. The presence of additional trace elements (i.e., calcium, zirconium, potassium, manganese, and zinc) was related to inclusions at or just below the surface of the area analyzed.

Chemical fluctuations between consecutive periods of crystal growth, as well as a preferential crystallographic orientation of the color-causing mechanisms of $\mathrm{Cr}^{3+}$ (ruby) or $\mathrm{Fe}^{2+} \leftrightarrow \mathrm{Ti}^{4+}$ (blue sapphire),

Figure 30. Many of the rubies and fancy-color sapphires from Jegdalek revealed infrared absorption bands at 3320 and $3085 \mathrm{~cm}^{-1}$ and weaker peaks at 2100 and $1980 \mathrm{~cm}^{-1}$. These indicate the presence of boehmite, which was seen in veins or lining parting planes. Such absorption characteristics are helpful not only in identifying foreign mineral phases that may be present, but also for indicating that the gem has not been heat treated.

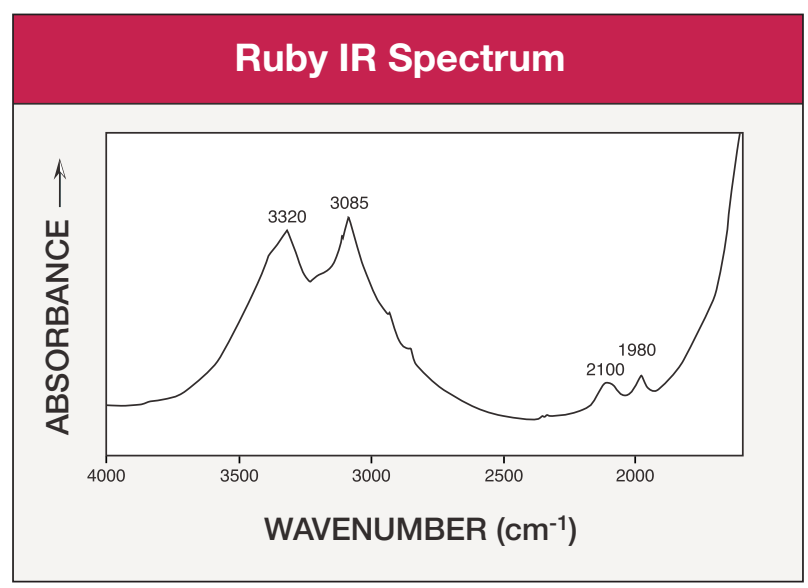

TABLE 2. Semi-quantitative chemical analyses by EDXRF for rubies and fancy-color sapphires from Jegdalek, Afghanistan.

\begin{tabular}{lccc}
\hline $\begin{array}{l}\text { Oxide } \\
\text { (wt.\%) }\end{array}$ & $\begin{array}{c}\text { Rubies } \\
(16)^{\mathrm{a}}\end{array}$ & $\begin{array}{c}\text { Fancy-color } \\
\text { sapphires (20) }\end{array}$ & $\begin{array}{c}\text { Blue } \\
\text { sapphire (1) }\end{array}$ \\
\hline $\mathrm{Al}_{2} \mathrm{O}_{3}$ & $92.9-99.6^{\mathrm{b}}$ & $99.1-99.7^{\mathrm{b}}$ & 99.3 \\
$\mathrm{Cr}_{2} \mathrm{O}_{3}$ & $0.250-1.971$ & $0.037-0.445$ & 0.009 \\
$\mathrm{TiO}_{2}$ & $0.002-0.078$ & $0.008-0.145$ & 0.046 \\
$\mathrm{Fe}_{2} \mathrm{O}_{3}$ & $0.016-0.174$ & $0.068-0.431$ & 0.068 \\
$\mathrm{~V}_{2} \mathrm{O}_{5}$ & $0.013-0.062$ & $0.005-0.035$ & 0.012 \\
$\mathrm{Ga}_{2} \mathrm{O}_{3}$ & $0.003-0.031$ & $0.009-0.061$ & $\mathrm{nd}^{\mathrm{c}}$ \\
\hline
\end{tabular}

${ }^{a}$ Number of samples are shown in parentheses. Trace-element analyses by ICP-AES were also obtained for one medium red ruby: 0.31 wt. \% CaO, 0.006 wt. $\% \mathrm{~V}_{2} \mathrm{O}_{5}, 0.35$ wt. $\% \mathrm{Cr}_{2} \mathrm{O}_{3}, 0.36$ wt.\% FeO, 0.17 wt. \% MgO, 0.20 wt. \% K $\mathrm{K}_{2} \mathrm{O},<30 \mathrm{ppm} \mathrm{Mn}, 50 \mathrm{ppm} \mathrm{Cu}$, 370 ppm Zn, 36 ppm Sr, 45 ppm Nb, 8 ppm Ba, 32 ppm Pb; $\mathrm{Be}$ and Ga were below the detection limits of $8 \mathrm{ppm}$ and $30 \mathrm{ppm}$, respectively. See also EDXRF analyses of Jegdalek rubies reported by Muhlmeister et al. (1998).

${ }^{b}$ The $\mathrm{Al}_{2} \mathrm{O}_{3}$ concentration of some samples was reduced by the presence of other minor and trace elements from mineral inclusions located at or just below the surface of the area measured.

c Not detected.

are responsible for the color zoning observed in the samples.

\section{DISCUSSION}

A few previous studies have documented some of the gemological characteristics of corundum (primarily rubies) from this deposit (Bowersox, 1985, 1995; Hughes, 1994, 1997). In general, our results are consistent with those of other studies, although certain mineral inclusions described by Hughes (1994, 1997) were not encountered during this study. These include macro-size crystals of garnet, chondrodite, spinel, hornblende, and dolomite.

Since this study included only one blue sapphire and the majority of the fancy-color sapphire samples were lower quality, it will not be possible to do a competent comparison to similar-colored sapphires from other marble-type sources. Therefore, the bulk of this discussion will compare Jegdalek rubies with those from other deposits.

If one uses the combination of inclusion patterns (e.g., clouds, "flakes" [actually, groups of pinpoints], and stringers, specific mineral inclusions, internal growth structures, and chemical composition, it should not be a problem to separate Afghan rubies from those of basaltic deposits (e.g., Thailand, Laos, Cambodia, and Australia), or metasomatic deposits (e.g., Madagascar, Tanzania, and Kenya). In general, Afghan rubies and fancy-color sapphires are similar to those from other marble-type sources (e.g., Southeast Asia and Africa, as well as Pakistan and 
Tajikistan). However, the specific inclusion features and internal growth structures of the Afghan rubies closely resemble those found at only a few of these deposits: Nepal, Mong Hsu (Myanmar), northern Vietnam, and, to a lesser degree, Tajikistan. Therefore, we shall limit the discussion of source distinction to comparison with ruby deposits in Nepal, Mong Hsu, and northern Vietnam. Note that the internal features that separate Jegdalek rubies from those of other localities will also clearly separate them from most synthetic corundum.

Nepal. There are several similarities between Afghan rubies and those from Nepal (see Harding and Scarratt, 1986; Kiefert and Schmetzer, 1986, 1987; Bank et al., 1988; Smith et al., 1997), and their separation may not be possible in all cases. For example, rubies from both localities may contain large rutile crystals and zones of short, very fine rutile needles (see figure 25); transparent colorless crystals of calcite and margarite; and $\mathrm{AlO}(\mathrm{OH})$ [both diaspore and boehmite]. However, there are some noteworthy distinctions. On the one hand, the euhedral, hexagonal, and rod-shaped crystals of apatite identified in rubies from Nepal were not encountered in the rubies from Jegdalek. On the other, the rounded colorless crystals of zircon in the Jegdalek samples have not been reported in Nepalese ruby. Similarly, while rubies from both localities contain partially healed fracture planes, only in the Afghan stones was a "frosted" texture noted on these planes.

The iron-sulfide inclusions and bluish white zonal clouds seen in some Afghan rubies (see figures 23 and 28, respectively) were not present in the Nepal samples. In contrast, uvite tourmaline, anorthite feldspar, and a black mineral grain surrounded by minute rutile needles documented in Nepal samples were not seen in the Afghan samples. Geometric platelets of graphite were noted in many of the Jegdalek samples, as were graphite scales in negative crystals (see figure 24). In the Nepal rubies, graphite was present only as coarse grains, often within larger mineral inclusions. The various flakelike and other inclusion patterns of the Jegdalek rubies were not observed in the Nepal rubies, whereas the antennae-like inclusion patterns so prevalent in Nepal rubies were not seen in the Jegdalek stones.

Although the internal growth structures and color zoning of corundum from both sources are almost identical, the wedge-shaped or wispy blue color zones in the Nepal stones are unique.
Mong Hsu. Rubies from Mong Hsu (Smith and Surdez, 1994; Smith, 1995; Peretti et al., 1995) and Jegdalek may seem similar at first, but a thorough investigation should reveal distinct differences. First, to remove the dark violetish blue color zone in the core of Mong Hsu rubies, the vast majority are heat treated. Therefore, an unheated ruby probably is not from Mong Hsu.

Macro-size mineral inclusions, although relatively common in the Jegdalek samples, are encountered infrequently in Mong Hsu rubies. Minerals identified as inclusions in Mong Hsu rubies to date include crystals of dolomite, apatite, diaspore, rutile, fluorite, and spinel.

"Cross-hatch," flake-like, and stringer formations are characteristic of rubies from Mong Hsu. Although the flake-like and stringer formations in rubies from Jegdalek (see, e.g., figure 26) may appear similar, closer scrutiny will reveal the unique texture, concentration, and crystallographic association of these inclusions in the Mong Hsu rubies.

The differences in internal growth structures are also conclusive. In Mong Hsu rubies, the prominent $c, r, n, \omega$ growth sequence, combined with the $c, n$ core zone formation, contrasts sharply with the mostly subtle $z, n$, and $r$ structures present in the Jegdalek samples.

Northern Vietnam. There are several similarities between rubies from northern Vietnam (Kane et al., 1991; Smith, 1996) and Afghanistan, and their separation may prove impossible in some cases. Rubies from both sources are known to contain macro-sized crystals of rutile, as well as zones of short, very fine rutile needles. However, long, iridescent rutile needles have not been recorded in Jegdalek rubies. Transparent colorless crystals of calcite, apatite, and zircon, as well as the general presence of $\mathrm{AlO}(\mathrm{OH})$ [both diaspore and boehmite], in addition to the very fine-grained bluish white clouds, also do not offer much insight into the probable source. However, the rod-shaped crystals of calcite identified in rubies from northern Vietnam were not encountered in the Jegdalek rubies. Conversely, neither the "frosted" texture noted in the healed fracture planes of the Afghan stones (see figure 19), nor the iron-sulfide inclusions that line fracture or parting planes (see figure 22), have been seen in Vietnamese rubies.

Pyrrhotite occurs as black rods in Vietnamese rubies, and the epigenetic inclusion nordstrandite may be present. However, Vietnamese rubies have not been seen to contain the geometric platelets of 


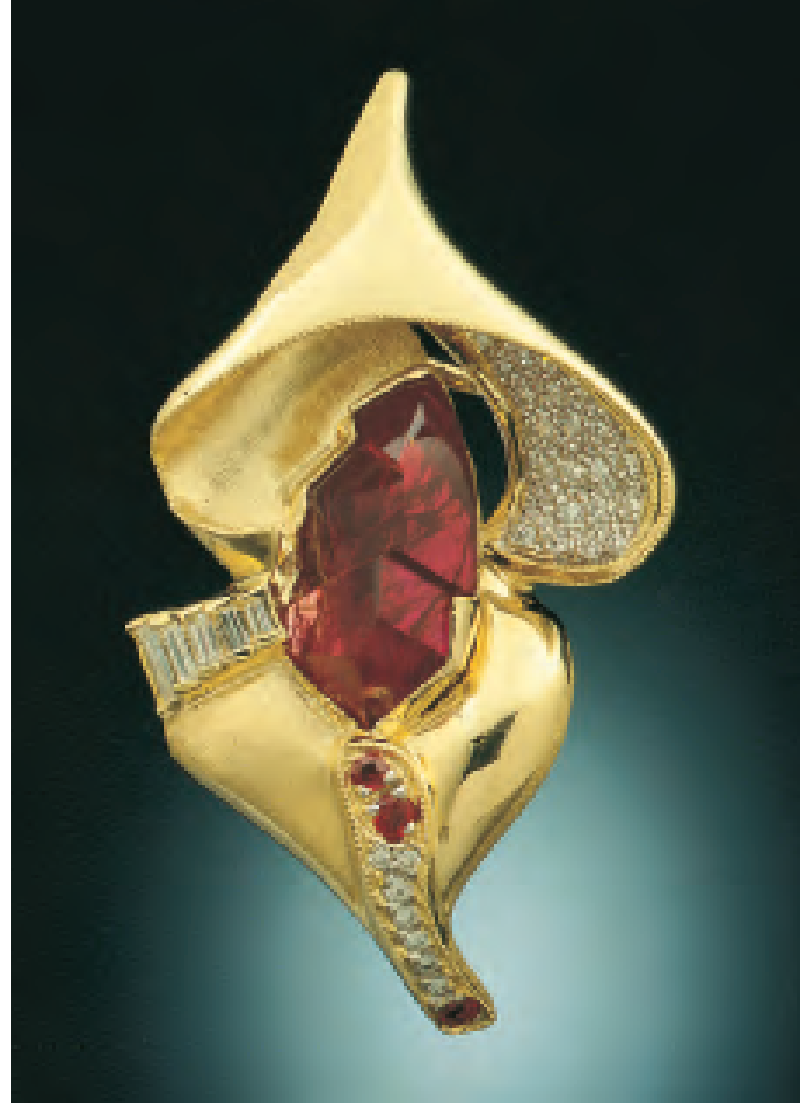

Figure 31. The Jegdalek deposits should continue to produce attractive ruby and pink sapphires. The $10.88 \mathrm{ct}$ ruby in this $18 \mathrm{~K}$ pendant/brooch has been carved in the Glyptic Illusion style. The piece was designed by Beverly Bevington and manufactured by Gary Mills. Photo by Jeffrey Scovil.

graphite noted in many of the Jegdalek samples, nor the graphite scales present in the negative crystals.

Although there are many similarities in the flakelike and other inclusion patterns of the rubies from both sources, the flake-like inclusions in many Jegdalek samples have a coarser texture. The internal growth structures and color zoning also may be similar, although rubies from northern Vietnam frequently show prominent growth structure sequences, which we have not observed in the Afghan samples. In addition, Vietnamese rubies reveal a much wider range of dipyramidal crystal habits, including additional crystal faces of the dipyramids $v$ and $\omega$ and the negative rhombohedron $d$.

Trace Elements. The concentrations of $\mathrm{V}, \mathrm{Ti}, \mathrm{Fe}$, and Ga may provide some evidence for locality determination, although the specific distinctions are very subtle and beyond the scope of this article.

Infrared Spectra. Certain trends were evident when absorption features related to $\mathrm{AlO}(\mathrm{OH})$ inclusions were present. Boehmite-related features were seen more frequently in rubies from Jegdalek, Nepal, and
Vietnam, whereas rubies from Mong Hsu more typically revealed absorption bands related to diaspore. However, when dominant IR absorption bands between approximately 2600 and $3800 \mathrm{~cm}^{-1}$ are quite strong, a clear distinction between diaspore and boehmite is not always possible. The presence of $\mathrm{AlO}(\mathrm{OH})$ in the spectrum also may provide welcome proof that a ruby is not heat treated, as well as a very good indication of whether it is natural or synthetic.

\section{CONCLUSION}

Over the past century, the Jegdalek deposit in eastcentral Afghanistan has supplied large quantities of cabochon-grade ruby (figure 31), and pink sapphire to the gem trade. Some very fine stones from this locality have also been cut. The semitransparent to translucent nature of the material is due to dense concentrations of fractures, as well as to the high degree of twinning in some samples. The most commonly observed internal features are partially healed and nonhealed fracture planes, lamellar twin planes parallel to $r$, color zoning (i.e., red/pink and blue areas), and mineral inclusions of calcite, apatite, zircon, mica, iron sulfides, graphite, rutile, and aluminum hydroxide. Rubies from Jegdalek usually can be separated from those of other localities by evaluating a combination of the inclusion patterns, mineral inclusions, and internal growth structures.

Although the Jegdalek deposit has the potential for year-round production of rubies and fancy-color sapphires that are suitable for fine jewelry, exploration and mining have been hindered by the political environment in Afghanistan. Although local tribal leaders are interested in using modern technology and equipment to increase production, they must wait until a stable and favorable government is formed in Kabul.

Acknowledgments: The authors acknowledge the assistance of the following individuals:

Commanders Ahmed Shah Massoud, Mahmud, Anwar Khan, and Alhaj Moulawi Ahmadjan (Minister of Mines and Industry) for providing the senior author with permission, transportation, and security for visiting the mining area; and Commander Sher Mohammed, Jamal Khan, Engineer Abdul Hakim, Khudai Nazar Akbari, Mir Waees Khan, Commander Mohammed Omar Tahdar, and Abdul Rafi for their field work with the exploration team. Nancy Dupree (Peshawar, Pakistan) and Abdul Aurab (ex-Minister of Mineral 
Promotion, Kabul, Afghanistan) furnished information on the tribal people and the history of ruby mining in the Jegdalek area. Sam Muhlmeister and Dino DeGhionno (both of the GIA Gem Trade Laboratory, Carlsbad) assisted with some of the Raman analyses and gemological studies. John Koivula is thanked for Raman analyses and photomicrography. Larry Snee (U.S. Geological Survey, Denver, Colorado) provided helpful comments on the manuscript.

\section{REFERENCES}

Bank H., Gübelin E., Harding H.H., Henn U., Scarratt K. Schmetzer K. (1988) An unusual ruby from Nepal. Journal of Gemmology, Vol. 21, No. 4, pp. 222-226.

Barlow A.E. (1915) Corundum: Its Occurrence, Distribution, Exploitation, and Uses. Department of Mines, Government Printing Bureau, Ottawa, Canada.

Bowersox G.W. (1985) A status report on gemstones from Afghanistan. Gems e) Gemology, Vol. 21, No. 4, pp. 192-204.

Bowersox G.W., Chamberlin B.E. (1995) Gemstones of Afghanistan. Geoscience Press, Tucson, 221 pp.

Bretschneider E. (1887) Medieval Researchers from Eastern Asiatic Sources. Kegan Paul, Trench, Trubner \& Co., London, $334 \mathrm{pp}$.

Debon F., Afzali H., Le Fort P., Sonet J. (1987) Major intrusive stages in Afghanistan: typology, age and geodynamic setting. Geologische Rundschau, Vol. 76, No. 1, pp. 245-264.

Farmer V.C. (1974) The infrared spectra of minerals. Mineralogical Society Monograph 4, Mineralogical Society, London.

Griesbach C.L. (1886) Afghan and Persian field notes. Records of the Geological Survey of India, Vol. 19, Pt. 1, pp. 48-65.

Griesbach C.L. (1892) The geology of the Safed Koh. Records of the Geological Survey of India, Vol. 25, Pt. 2.

Gübelin E.J. (1982) Gemstones of Pakistan: Emerald, ruby, and spinel. Gems ef Gemology, Vol. 18, No. 3, pp. 123-139.

Haas H. (1972) Diaspore-corundum equilibrium determined by epitaxis of diaspore on corundum. American Mineralogist, Vol. 57, pp. 1375-1385.

Harding R.R., Scarratt K. (1986) A description of ruby from Nepal. Journal of Gemmology, Vol. 20, No. 1, pp. 3-10.

Hughes R.W. (1994) The rubies and spinels of Afghanistan: A brief history. Journal of Gemmology, Vol. 24, No. 4, pp. 256-267.

Hughes R.W. (1997) Ruby \&) Sapphire. RWH Publishing, Boulder, 512 pp.

Kane R.E. (1997) Kashmir ruby-a preliminary report on the deposit at Nangimali, Azad Kashmir, Pakistan. Proceedings of the 26th International Gemological Congress, Sept. 27 to Oct. 3, Idar-Oberstein, Germany, pp. 28-30.

Kane R.E., McClure S.F., Kammerling R.C., Khoa N.D., Mora C., Repetto S., Khai N.D., Koivula J.I. (1991) Rubies and fancy sapphires from Vietnam. Gems Æ Gemology, Vol. 27, No. 3 , pp. 136-155.

Kazmi A.H. (1989) A brief overview of the geology and metallogenic provinces of Pakistan. In A.H. Kazmi and L.W. Snee, Eds., Emeralds of Pakistan: Geology, Gemology, and Genesis. Van Nostrand Reinhold, New York, pp. 1-11.

Kiefert L., Schmetzer K. (1986) Rosafarbene und violette Sapphire aus Nepal. Zeitschrift der Deutschen Gemmologischen Gesellschaft, Vol. 35, pp. 113-125.

Kiefert L., Schmetzer K. (1987) Pink and violet sapphires from Nepal. Australian Gemmologist, Vol. 16, No. 6, pp. 225-230.

Kiefert L., Schmetzer K. (1991) The microscopic determination of structural properties for the characterization of optical uniaxial natural and synthetic gemstones, part I: General considera- tions and description of the methods. Journal of Gemmology, Vol. 22, No. 6, pp. 344-354.

Liddicoat R.T. Jr. (1989) Handbook of Gem Identification, 12th rev. ed. Gemological Institute of America, Santa Monica, CA.

Muhlmeister S., Fritsch E., Shigley J.E., Devouard B., Laurs B.M. (1998) Separating natural and synthetic rubies on the basis of trace-element chemistry. Gems «) Gemology, Vol. 34, No. 2, pp. 80-101.

Okrusch M., Bunch T.E., Bank H. (1976) Paragenesis and petrogenesis of a corundum-bearing marble at Hunza (Kashmir) Mineralium Deposita, Vol. 11, pp. 278-297.

Orlov G.A., Tsabolov G.S., Eriomenko G.K., Zhdan A.V., Matveev P.S., Ghawari S.A. (1974) Report by the Jegdalek Crew on the Work in 1973-74. Department of Geological and Mineral Survey, Kabul.

Peretti A., Schmetzer K., Bernhardt H.-J., Mouawad F. (1995) Rubies from Mong Hsu. Gems « Gemology, Vol. 31, No. 1, pp. 2-26.

Powell C.A., Conaghan P.J. (1973) Plate tectonics and the Himalayas. Earth and Planetary Science Letters, Vol. 20, pp. $1-20$.

Rossovsky L.N. (1980) Mestorozhdeniya dragotsennykh kamney Afghanistana [Gemstone deposits of Afghanistan]. Geologiya Rudnykh Mestorozhdenii [Geology of Ore Deposits], Vol. 22, No. 3, pp. 74-88.

Schmetzer K. (1986a) An improved sample holder and its use in the distinction of natural and synthetic ruby as well as natural and synthetic amethyst. Journal of Gemmology, Vol. 20, No. 1 , pp. 20-33.

Schmetzer K. (1986b) Natürliche und synthetische RubineEigenschaften und Bestimmung. Schweizerbart, Stuttgart, Germany.

Shareq A., Chmyriov V.M., Stazhilo-Alekseev K.F., Doronov V.I., Gannon P.J., Lubemov B.K., Kafarskiy A.Kh., Malyarov E.P., Rossovsky L.N. (1977) Mineral Resources of Afghanistan, 2nd ed. United Nations Development Program, AFG/74/012, 419 pp.

Smith C.P. (1995) Contribution to the nature of the infrared spectrum for Mong Hsu rubies. Journal of Gemmology, Vol. 24, No. 5, pp. 321-335.

Smith C.P. (1996) Introduction to analyzing internal growth structures: Identification of the negative $d$ plane in natural ruby. Gems ↔ Gemology, Vol. 32, No. 3, pp. 170-184.

Smith C.P. (1998) Rubies and pink sapphires from the Pamir Mountain Range in Tajikistan, former USSR. Journal of Gemmology, Vol. 26, No. 2, pp. 103-109.

Smith C.P., Surdez N. (1994) The Mong Hsu ruby: A new type of Burmese ruby. JewelSiam, Vol. 4, No. 6, pp. 82-98.

Smith C.P., Gübelin E.J., Bassett A.M., Manandhar M.N. (1997) Rubies and fancy-color sapphires from Nepal. Gems 4 Gemology, Vol. 33, No. 1, pp. 24-41.

Sorkhabi R.B., Stump E. (1993) Rise of the Himalaya: A geochronologic approach. GSA Today, Vol. 3, No. 4, pp. 85, $88-92$.

Webster R. (1994) Gems: Their Sources, Descriptions, and Identification, 5th ed. P. G. Read, Ed., ButterworthHeinemann, London.

Wefers K., Bell G.M. (1972) Oxides and Hydroxides of Alumina, Alcoa Research Laboratories Technical Paper No. 19, Alcoa Research Laboratories, St. Louis, MO.

Wefers K., Misra C. (1987) Oxides and Hydroxides of Alumina, Alcoa Research Laboratories Technical Paper No. 19, Revised. Alcoa Research Laboratories, St. Louis, MO.

Wood J. (1841) A Journey to the Source of the River Oxus. London, John Murray, 2nd ed., 1872, reprinted 1976, Oxford University Press, $280 \mathrm{pp}$.

Wyart J., Bariand P., Filippi J. (1981) Lapis-lazuli from Sar-e-Sang, Badakhshan, Afghanistan. Gems e) Gemology, Vol. 17, No. 4, pp. 184-190. 